\title{
Serotonin and cardiovascular diseases
}

\author{
Laurent Monassier ${ }^{2}$, and Luc Maroteaux ${ }^{1}$ \\ ${ }^{I}$ INSERM UMR-S 839, F75005, Paris, France; Université Pierre et Marie Curie, F75005, \\ Paris, France; Institut du Fer à Moulin, F75005, Paris, France. \\ ${ }^{2}$ Laboratoire de Neurobiologie et Pharmacologie Cardiovasculaire (EA7296), Faculté de \\ Médecine, Fédération de Médecine Translationnelle, Université et Centre Hospitalier de \\ Strasbourg, F67000 Strasbourg, France.
}

Serotonergic dysfunction is mainly associated with neuropsychiatric and cardiovascular disorders but has also been linked with many other pathological conditions. This review provides an overview of the recent pharmacological developments involving 5hydroxytryptamine (5-HT; serotonin), released from blood platelets, in the human cardiovascular system. The acute cardiovascular response to serotonin, named the BezoldJarish reflex, leads to intense bradycardia associated with atrioventricular block, and involves $5-\mathrm{HT}_{3}, 5-\mathrm{HT}_{1 \mathrm{~B}}, 5-\mathrm{HT}_{7}$ and $5-\mathrm{HT}_{2 \mathrm{~A} / 2 \mathrm{~B}}$ receptors. The contribution of serotonin and its receptors $\left(5-\mathrm{HT}_{4}\right.$ and $\left.5-\mathrm{HT}_{2 \mathrm{~A} / 2 \mathrm{~B}}\right)$ in cardiac development, in cardiovascular tissue remodeling, with a particular emphasis on cardiac hypertrophy, fibrosis and failure, in valve degeneration, is explored in this review. Some new aspects of $5-\mathrm{HT}_{1 \mathrm{~B}}, 5-\mathrm{HT}_{7}$ and $5-\mathrm{HT}_{2 \mathrm{~A} / 2 \mathrm{~B}}$ receptors in vasomotor tone regulation and the interaction between endothelial and smooth muscle cells are also be discussed. As well, serotonin, its transporter, 5- $\mathrm{HT}_{1 \mathrm{~B}}$, and 5- $\mathrm{HT}_{2 \mathrm{~B}}$ receptors participation in pulmonary hypertension and pulmonary vascular remodeling are presented. Finally, the contribution of bone marrow derived endothelial progenitors in the pathogenesis of pulmonary hypertension and interactions with bone morphogenic protein type 2 receptor signaling are highlighted.

The aim of this review is thus to emphasize the vascular, cardiac and pulmonary effects caused by serotonin receptor activation, and to highlight their possible prevention by the development of new drugs targeting this system.

\section{Introduction}

Long before its identification as 5-hydroxytryptamine (5-HT), the first description of serotonin effects was about cardiovascular action. At the end of 19th century, physiologists had already observed that a substance present in serum, acellular fraction from thrombosed blood, acted on heart and vessels: German physiologists realized that blood serum was not a biologically inert substance since in 1896, Weiss showed that intravenous injection of serum into an animal caused an increase in breathing and cardiac frequencies, followed by a rapid decrease in blood pressure leading eventually to death by shutdown of respiratory system (Weiss, 1896). Later, in 1918, it was reported that uncoagulated blood or citrated plasma did not have a vasoconstrictor action, while citrated serum or blood platelet extracts (but not from leucocytes or erythrocytes) were clearly vasoconstrictors (Janeway, et al., 1918). Then, it was not until early 1930 s that a substance that contracted smooth muscles was isolated from intestinal enterochromaffin cells. It was called enteramine (Vialli \& Erspamer, 1933). Finally, in late 1940s, Page, Green and Rapport isolated a vasoconstrictor substance that they called serotonin before it was identified as 5-hydroxytryptamine (Rapport, et al., 1948a, 1948b).

In adult organism, serotonin is mainly stored in dense granules of blood platelets from which it is released during activation and/or aggregation phenomena, causing previously described vasoconstrictive effects. This circulating stock results from load by platelets of serotonin synthesized in intestinal wall. Serotonin is independently synthesized in raphe nuclei, a structure in brainstem of central nervous system, which also participates in 
cardiovascular regulation. In periphery, this mediator contributes to control many cardiovascular functions since, in addition to effects on platelet aggregation and hematopoietic stem cells differentiation, serotonin can modulate blood pressure, heart rate and respiration. Finally, it has a major pathophysiological role in metastatic neuroendocrine carcinoid tumors. Carcinoid tumors are neuroendocrine tumors originating from enterochromaffin cells that develop within the digestive tract and secrete large amounts of serotonin (Wilkinson \& Dourish, 1991). The cardiovascular functions of serotonin, often unrecognized, have recently been re-evaluated in particular in cerebral and pulmonary circulatory beds with development of "serotonergic" drugs for treatment of migraines and likely in a near future in primary pulmonary arterial hypertension (PAH) and valvular heart diseases (VHD).

It may be surprising that a unique mediator possesses so many different functions. This diversity can be explained by the fact that serotonin acts through numerous receptors. Gaddum and Picarelli (1957), working on guinea pig ileum, proposed that serotonin acts, on two pharmacologically different receptors, $M$ (muscarin-sensitive) and D (dibenzylinsensitive) receptors located on smooth muscles and neurons respectively. During early 90s, identification of serotonin receptor genes has progressed considerably with gene cloning and sequencing techniques. It now appears that there are 15 different receptor genes, divided into four subtypes: 5- $\mathrm{HT}_{1 / 5}, 5-\mathrm{HT}_{2}, 5-\mathrm{HT}_{3}$, and 5- $\mathrm{HT}_{4 / 6 / 7}$ (Alexander, et al., 2013). These receptors are grouped according to their intracellular coupling mode. 5- $\mathrm{HT}_{3}$ receptors are ion channels whereas all others are G-protein coupled receptors: Gi proteins for 5-HT $\mathrm{H}_{1 / 5}$, Gs for 5- $\mathrm{HT}_{4 / 6 / 7}$ and finally $\mathrm{Gq}$ for $5-\mathrm{HT}_{2}$. Subfamilies have been distinguished within these categories. Thus, for example, there are three members in 5- $\mathrm{HT}_{2}$ receptors $\left(5-\mathrm{HT}_{2 \mathrm{~A}}, 2 \mathrm{~B},{ }_{2} \mathrm{C}\right)$. In this chapter, we will present current state of knowledge about roles of serotonin, its transporter and its receptors in physiology and pathology of cardiovascular system.

\section{Serotonin in cardiac morphogenesis.}

Serotonin is present at early stages of embryogenesis and is synthesized during zygotic cleavages, gastrulation and neurulation (Amireault \& Dube, 2005; Lauder, 1993). Serotonin appears necessary for the formation of heart: immunolabeling studies with antibody directed against serotonin revealed that the myocardium of mice embryos (E8-11) grown in the presence of serotonin can take up this mediator avidly. Thereafter, uptake decreases to be restricted to endocardial cushions. Thymidine incorporation experiments show that serotonin, reuptake inhibitors, fluoxetine or sertraline, inhibit proliferation of cardiac mesenchyme, endocardium and myocardium especially at E9 (before cushion formation). Serotonin therefore participates in cardiac morphogenesis before and during formation of endocardial cushions (Yavarone, et al., 1993) (see below).

\subsection{Expression and function 5-HT $\mathrm{T}_{2 \mathrm{~A}}$ and $5-\mathrm{HT}_{2 \mathrm{~B}}$ receptors in embryonic heart}

In mice, expression of $5-\mathrm{HT}_{2 \mathrm{~A}}$ and $5-\mathrm{HT}_{2 \mathrm{~B}}$ receptors is observed during active phases of morphogenesis in neuroepithelium, notochord, somites, neural crest cells, craniofacial mesenchyme, myocardium and endocardial cushions, dental germs, hair follicles, cartilage and striated muscles (Choi, et al., 1997; Lauder, et al., 2000). In mouse embryo culture experiments, antagonists of high affinity for $5-\mathrm{HT}_{2 \mathrm{~B}}$ receptor such as ritanserin (but not ketanserin, a 5- $\mathrm{HT}_{2 \mathrm{~A}}$ preferential antagonist) cause morphological deficits in cephalic, cardiac and neural tube regions. These treatments interfere with migration of neural crest cells and cause their apoptosis (Choi, et al., 1997). With regard to heart formation, these treatments lead to an abnormal organization of sarcomeres of subepicardial layer and to the absence of myocardial trabeculation. 
This evidence for a role of $5-\mathrm{HT}_{2 \mathrm{~B}}$ receptors in heart formation was confirmed by creation of mutant mice for these receptors by homologous recombination (KO-Htr $\left.2 b^{--}\right)$. This inactivation causes abnormalities in cardiac development leading to partial embryonic and perinatal lethality. This lethality observed at E10-12 can be attributed to a cardiac deficit. Embryonic abnormalities induced by lack of 5- $\mathrm{HT}_{2 \mathrm{~B}}$ receptor expression are similar to those resulting from the absence of genes encoding neuregulin or its ErbB-2 receptor. Htr $2 b^{-/}$ mouse embryos show changes in expression of ErbB-2 and its effectors. It appears therefore that $5-\mathrm{HT}_{2 \mathrm{~B}}$ receptors coupled to $\mathrm{Gq}$ use signaling pathway of ErbB-2 receptor tyrosine kinases for cardiac differentiation (Nebigil, et al., 2000b).

$H t r 2 b^{-/}$mice that survive embryogenesis present abnormalities at birth with ventricular dilatation mainly involving left ventricle and disruption of myofibrils. In addition, myocytes isolated from newborns of $\mathrm{Htr}_{2} \mathrm{~b}^{-/}$mutant mice exhibit anomalies in contractile response following a pharmacological or mechanical stimulus. These morphological and functional deficits appear to be greater in young adult males than in female mutant mice. This gender difference in cardiac expression of a genetic deficiency is frequently observed in mice. As an example, mutant males for alpha myosin heavy chain (familial cardiomyopathy model) are more affected than females at the same age. In $\mathrm{Htr} 2 \mathrm{~b}^{-/}$mice, reduction in myocytes size is accompanied by a reduction in their number. This result is corroborated by decreased thymidine incorporation by cells derived from newborn mutant hearts. Finally, Htr $2 b^{-/}$ newborn heart presents major cytoarchitectural abnormalities with severe reduction in NCadherin expression and intercellular junctions (discs) with many ultrastructural abnormalities (Nebigil, et al., 2000a).

\subsection{Expression and function of 5-HT 4 in embryonic heart}

In mice, mRNA encoding 5- $\mathrm{HT}_{4}$ receptor is elevated in embryonic heart at E12. Its expression decreases and then disappears at birth supporting its participation in heart development. In humans, this expression seems to persist and could be strongly induced in pathological situations. A role for $5-\mathrm{HT}_{4}$ receptors has been identified in newborn lupus erythematous supporting its functions during embryogenesis: female mice immunized against the second extracellular loop of 5- $\mathrm{HT}_{4}$ receptor give birth to pups with important intracardiac disorders, especially atrioventricular blocks of varying degrees, growth retardation, and spina bifida (Kamel, et al., 2007).

\subsection{Expression and function of serotonin transporter (SERT) in embryonic heart}

Numerous evidences indicate a role of serotonin and serotonin transporter (SERT), Slc6a4, in cardiac development. Indeed, this membrane transporter participates in regulation of extracellular levels of serotonin. Using a Cre/lox conditional expression system using SERT promoter, distribution of SERT in heart development has been monitored. Its expression follows that of Islet1 (Is11) (Laugwitz, et al., 2005) and connexin-43 (Cx-43) (Pavone, et al., 2008). Co-labeling of SERT with Isl1 is visible in ventricular ejection pathway and right ventricle at E11.5 and co-labeling with connexin-43 (Cx-43) in atrio-ventricular valves was also revealed. These observations suggest a role for SERT in cardiomyocytes and in valves during cardiac development (Pavone, et al., 2008). This observation may be related to the observation of a combination of maternal use of serotonin reuptake inhibitors (SSRI), persistent pulmonary hypertension in newborn (Chambers, et al., 2006) and cardiac development abnormalities (Louik, et al., 2007).

\subsection{Maternal origin of serotonin}

In patients with inherited phenylketonuria (PKU), phenylalanine hydroxylase enzyme activity is defective resulting in a serum elevation of phenylalanine concentration (Lenke \& Levy, 
1980). A consequence of this hyperphenylalaninemia is secondary inhibition of tyrosine- and tryptophan-hydroxylases leading to very low catecholamines and serotonin levels in blood (Roux, et al., 1995). Diet with reduced phenylalanine is fundamental in PKU women during their pregnancy. In the absence of such a diet, women with PKU give birth to babies with irreversible cardiac (cardiopathies) and cerebral abnormalities (mental retardation). It therefore appears that embryonic development requires normal plasma concentrations of catecholamines and serotonin in the mother. To explore this hypothesis, animal models of PKU have been developed. In particular, mouse embryos grown in serum of patients with PKU develop embryonic defects that are corrected if serum is supplemented with serotonin (Roux, et al., 1995). Maternal serotonin deficiency seems therefore a key factor in teratology of phenyketonuria women. Interestingly, treatment of mouse embryos with selective 5- $\mathrm{HT}_{2}$ antagonists produces similar deficits (Choi, et al., 1997). It may therefore be hypothesized that the absence of stimulation of receptors by serotonin would be responsible, at least in part, for these abnormalities. These observations support that serotonin is required for embryogenesis and has a maternal origin in mammals, at least during early embryogenesis before placenta formation (Saugstad, 1977).

\section{Adult origin of serotonin}

Peripheral and non-neuronal serotonin is released by intestinal neuroendocrine cells to the portal venous system and is then actively captured by blood platelets within the pulmonary vasculature. In fact, platelets rapidly translocate into lung upon stimulation of 5-HT2 receptors, take up serotonin, and then return to circulation. Hence, pulmonary platelet accumulation plays an important role in pulmonary serotonin removal in mice ( $\mathrm{Yu}$, et al., 2009). Ablation of the peripheral tryptophan hydroxylase 1 (Tph1) gene in mice results in a significant reduction in peripheral, essentially blood serotonin. Nevertheless, there still remains 3 to $15 \%$ of normal concentration probably originating from a synthesis by neurons of mesenteric plexuses via neuronal subtype of TPH (Tph2). Cardiac functions of animals born from these mice are strongly affected with contractile abnormalities thus demonstrating critical functions of maternal serotonin on embryonic development (Cote, et al., 2007). Of course, this work does not exclude possible role of TPH1 in embryonic development.

\section{Role of 5-HT $2 \mathrm{~B}$ receptors in post-natal maturation and cardio- vascular development}

Cardiovascular effects of serotonin are complex (Villalón \& Centurión, 2007) and its contribution to myocardial physiological and pathological processes remains poorly understood. Congenital absence of $5-\mathrm{HT}_{2 \mathrm{~B}}$ receptors in $H t r 2 b^{-/}$mice leads to a large prenatal $(30 \%)$ and early neonatal $(30 \%)$ lethality linked in part to defects in maturation and differentiation of cardiomyocytes. This mutation leads to appearance of dilated cardiomyopathy in surviving mice (Nebigil, et al., 2000a). Nevertheless, about $40 \%$ of mutant animals reach adulthood and present, initially, dilated cardiomyopathy with plasma elevation of usual markers of myocardial necrosis (troponin I and CPK-MB) (Ayme-Dietrich, et al., 2015). This elevation is associated with a decrease in contractile parameters such as left ventricular shortening fraction measured by echocardiography. These lesions are very similar to those seen in dilated cardiomyopathy in humans or in mice invalidated for myosin heavy chains, which present ventricular dilatation and disorganization of myofibrils in adulthood. The response to $\beta$-adrenergic receptor agonist dobutamine in $H \operatorname{tr} 2 b^{-/-}$cardiomyocytes is impaired (Nebigil, et al., 2001). Serotonin via Gq-coupled 5- $\mathrm{HT}_{2 \mathrm{~B}}$ receptors protects newborn cardiomyocytes against serum deprivation-induced apoptosis as manifested by DNA 
fragmentation, nuclear chromatin condensation, and TUNEL labeling. Serotonin prevents cytochrome c release and caspase -9 and -3 , activation, after serum deprivation via cross talks between phosphatidylinositol-3 kinase/Akt and extracellular signal-regulated kinase ERK1/2 signaling pathways. Serotonin binding to $5-\mathrm{HT}_{2 \mathrm{~B}}$-receptor activates ERK kinases to inhibit Bax expression induced by serum deprivation. Serotonin via phosphatidylinositol-3 kinase/Akt can activate NF-kB that is required for regulation of mitochondrial adenine nucleotide translocator (ANT-1). Parallel to these observations, ultrastructural analysis in $H$ tr $2 b^{-/}$mice heart revealed pronounced mitochondrial defects in addition to altered mitochondrial enzyme activities (cytochrome oxidase and succinate dehydrogenase) and ANT-1 and Bax expressions. These findings identify serotonin as a survival factor targeting mitochondria in cardiomyocytes via 5- $\mathrm{HT}_{2 \mathrm{~B}}$ receptors (Nebigil, et al., 2003).

\section{Serotonin in adult heart}

\subsection{Serotonin origin in adult heart.}

The question of serotonin origin and its role in adult heart remains unclear, but several possibilities can be suggested. We have already mentioned that serotonin secreted by enterochromaffin cells of digestive tract is mainly stored in blood platelets. Sarpogrelate, a preferential $5-\mathrm{HT}_{2 \mathrm{~A}}$-receptor antagonist behaves as an antiplatelet, and antithrombotic agent due to inhibition of serotonin-induced platelet aggregation (Doggrell, 2004). From circulating stock, serotonin can also be captured by sympathetic neurons and endothelial cells and then released alone or with other bioactive amines such as noradrenaline. Recently, implication of serotonin in several cardiovascular diseases has been intensely studied.

Vikenes et al (1999) described high blood serotonin levels as a risk factor for coronary artery and cardiac diseases. A high level of plasma serotonin is correlated with primary pulmonary hypertension (Hervé, et al., 1995; Kéreveur, et al., 2000). In addition, serotonin may be responsible for, or participate in the maintenance of certain forms of systemic arterial hypertension. Watanabe et al., (2001) showed that serotonin can potentiate proliferative action of endothelin-1 in smooth muscle cells, a phenomenon often associated with hypertension or atherosclerosis. In addition, plasma levels of serotonin are elevated in patients with heart failure (HF) (Chandra, et al., 1994) and aortic valve stenosis (Rouzaud-Laborde, et al., 2015). Elevated levels of 5-HIAA and plasma atrial natriuretic peptide (ANP) were also reported in HF (Zuetenhorst, et al., 2003).

Some authors suggest that the myocardium itself can store and even synthesize serotonin. In humans, serotonin myocardial concentration is globally in the order of $0.4 \mu \mathrm{g} / \mathrm{g}$ of tissue (Sole, et al., 1979). TPH2 is expressed in human cardiac ganglia neurons, corroborating the idea of a local myocardial synthesis of serotonin (Singh, et al., 1999). In this case, synthesis would occur in cholinergic neurons since there are no sympathetic nerve ganglia in heart. Finally, serotonin may be taken up by sympathetic terminals of the atrium and then released upon stimulation, thus acting as a co-transmitter. However, conflicting results were published concerning cardiac expression of TPH1 especially by cardiomyocytes. Thus, species differences cannot be formally ruled out.

\subsection{Depression and cardiovascular risk.}

Serotonin is clearly involved in depressive disorder treatments. In patients with coronary artery disease, associated depression results in increased cardiovascular mortality. A relationship exists between depression and myocardial infarction (MI) since the severity of depression has been correlated with morbidity and mortality due to cardiac pathologies. During the 18 months following MI, severe depression is observed in $15-30 \%$ of patients. The reason for this comorbidity is not well understood, as many factors including toxicity of 
tricyclic antidepressants, cerebral arterial atheromatosis, which may favor depression or reduced observance of depressed patients, have been proposed (Somberg \& Arora, 2008). However, deregulation of the serotonergic system has also been suggested. Abnormal platelet bioavailability of serotonin could lead to a state of hyper-aggregability. In this context, depression would not be a cause of poor prognosis but merely a symptom attesting to central and/or peripheral serotoninergic dysfunction. SSRIs would be the treatment of choice for these depressions (Strik, et al., 2001). In support of this hypothesis, the SADHART study revealed efficacy, and safety profile of sertraline, an SSRI, in post-MI depression or in patients with unstable angina, but the power of this study was not sufficient to demonstrate a benefit on survival (Joynt \& O'Connor, 2005). However, further analysis showed that sertraline reduced platelet hyper-aggregability in depressed patients. Serotonin could be at the center of global, central and peripheral cardiovascular deregulations, resulting in cardiovascular defects and in left ventricular dysfunction.

Few studies have suggested possibility of a direct SERT modulation in cardiovascular organs. SERT is expressed in many cardiovascular sites, including heart, blood vessels, platelets and bone marrow. SERT is involved in modulation of cardiac or smooth muscle contractility, platelet aggregation, and/or vascular proliferation. Polymorphisms have been described in SERT promoter: the long $\mathrm{L}$ allele is associated with higher transcription of SERT gene compared to the short S allele (Heils, et al., 1996). This increase in transcription is measured by mRNA expression but also by higher serotonin uptake by lymphocytes in subjects carrying LL genotype compared to SS or LS genotypes (Lesch, et al., 1996). Studies have evaluated impact of SERT variants in cardiovascular diseases. MI risk of has been linked in some studies to the presence of homozygous LL genotype (Fumeron, et al., 2002; $\mathrm{Ni}$, et al., 2006). LL and LS genotypes are associated with an increase in platelet serotonin content and could therefore promote increased platelet "activability" (Hanna, et al., 1998); platelet activation is increased in patients depressed with homozygous LL allele thus contributing to an increased risk of ischemic heart disease (Whyte, et al., 2001) or coronary artery disease (Arinami, et al., 1999). Conversely, decreased SERT expression on platelets would reduce amount of available serotonin, and thus increase aggregation and thrombi formation. Patients with SS alleles are at lower risk of MI with higher age of onset than LLs (Coto, et al., 2003). These genetic data remain debatable as other (intronic) polymorphisms have been described in SERT gene and inter-ethnic variations in distribution of these alleles have been observed without correlation with cardiac pathologies (Gelernter, et al., 1999; Noskova, et al., 2008).

Antidepressants that inhibit SERT function prevent platelets from loading with serotonin (Hergovich, et al., 2000) and may thus reduce MI incidence (Sauer, et al., 2003). As mentioned above, clinical studies failed to demonstrate that SSRIs are effective in secondary MI prevention.

\section{Serotonin in carcinoid heart}

Carcinoid heart is a major complication of carcinoid tumors (Hart, et al., 2017; SimõesPereira, et al., 2017). These tumors are frequently associated to carcinoid syndrome that includes skin flushing, asthma and diarrhea (Fox \& Khattar, 2004; Goichot, et al., 2005). Incidence of carcinoid tumors increases between 55 and 60 years, and is about 1/75 000, of which 50\% will present carcinoid syndrome. This syndrome is due to massive release of serotonin by neuro-endocrine tumors mainly originating from ileum wall (Robiolio, et al., 1995). More rarely, appendicular, ovarian or pulmonary sites are identified. When the primary tumor is localized in the gastrointestinal tract, metastases can be observed, first in liver 
followed by lung. In primary ovarian cancer, venous drainage of this organ will lead to pulmonary metastases.

Valvular heart disease is found in about $50 \%$ of carcinoid patients. Mortality at 3 years is $70 \%$ vs. $35 \%$ in patients with carcinoid syndrome in the absence of cardiac disease. Cardiac lesions predominate on right heart side since left ventricle is protected from serotonin by lung metabolism, an organ that constitutes its main peripheral emunctory. A primary ileal tumor will secrete serotonin to venous blood portal system allowing a first hepatic metabolism and therefore limiting cardiac lesions and carcinoid syndrome. Lesions are more important for tumors whose initial drainage is not to liver. Patients with left ventricular lesions should be referred to as pulmonary tumors, but may also be observed following passage of serotonin through a foramen ovale, opening of which is favored by increase in right cardiac pressures associated with cardiopathy and pulmonary hypertension.

Apart from the clinical picture of carcinoid syndrome, the presentation of patients is globally not very specific. Roberts (1997) showed that patients usually have normal blood pressure and sometimes lowered weight; cardiac involvement was responsible for mortality in $43 \%$ of cases. Globally, cardiopathy of carcinoid syndrome is responsible for $25 \%$ of death. Anomalies observed at ECG are uncommon (30-50\% of carcinoid hearts) and non-specific: microvoltage, repolarization disorders, right branch block and more frequently sinus tachycardia (Pellikka, et al., 1993), which may be related to activation of atrial $5-\mathrm{HT}_{4}$ receptors. Chest X-ray may show an increase in heart size but it is mainly the presence of tricuspid and/or pulmonary signs on auscultation, which indicates cardiopathy. However, the presence of subclinical valvular lesions can only be detected by echocardiography. In total, independently of tumor sites, two key diagnostic tests in carcinoid syndrome are thus echocardiography and measurement of 24-hour urinary excretion of 5-hydroxyindole acetic acid (5-HIAA), the major metabolite of serotonin, which may increase 10-fold $(>50$ $\mu \mathrm{mol} / \mathrm{l} / 24 \mathrm{~h})$. This dosage should be done following withdrawal of tryptophan rich foods that can induce false positives: banana, nuts, kiwi, avocado and pineapple.

\subsection{Echocardiographic identification of carcinoid heart lesions.}

Cardiac involvement is characterized by formation of "carcinoid plaques" localized on atrial endocardium, superior vena cava, and coronary sinus arrival in right atrium but also and especially, on the downstream face of tricuspid and pulmonary artery valves (Roberts, 1997). Echocardiography permits visualization of thickened zones, retractions of tricuspid leaflets and sometimes calcifications. Among 74 patients with carcinoid heart disease $(74 / 132$ carcinoid syndromes or 56\%), Pellikka et al. (1993) showed that $97 \%$ of patients had tricuspid involvement and $88 \%$ had pulmonary valve disease, whereas only $7 \%$ (5 patients) had left heart valvular lesions. Of these 5 patients, 4 had either a permeable foramen ovale or pulmonary tumor localizations. Tricuspid valve-insufficiency is more frequently found $(90 \%$ of the cases), whereas pulmonary valve involvement represents $88 \%$ of the cases in diastole and, $53 \%$ in systole. Hemodynamic disorders, which result from these valvular lesions, can lead to dilation of right cardiac cavities and to a contractile failure. In this context, it is difficult to evaluate pulmonary pressures and only few studies have performed a right cardiac catheterization in these patients. Nevertheless, limited data available suggest that some patients have associated pulmonary arterial hypertension.

\subsection{Anatomopathologic and histologic properties of carcinoid heart lesions.}

Histologically, plaques appear to be composed of smooth muscle cells surrounded by a stroma of collagen and mucopolysaccharides (Ferrans \& Roberts, 1976). On the other hand, no elastic fibers are found. These smooth muscle cells could be derived from mesenchymal cells found in the subendocardium. Plaques can also be found in tricuspid appendages and 
papillary muscles. These lesions were initially interpreted as cicatricial reactions to repair necrotic regions, but their localization in areas of hemodynamic turbulence could indicate a reaction to local concentration of circulating substances. Carcinoid plaques by shrinking, shorten tricuspid valve leaflet length, and generate valvular insufficiency. Leak is favored by development of adhesions between ventricular face of leaflet and endocardium. Coexistence of tricuspid insufficiency and pulmonary stenosis is probably a major factor in severity of this disorder.

\subsection{Implication of serotonin in carcinoid heart lesions.}

Carcinoid tumors release many mediators such as bradykinin, histamine, prostaglandins, substance P and serotonin. Carcinoid tumors can synthesize such large amount of serotonin that patients may develop skin lesions typical of pellagra (brownish pigmentation of sunexposed areas) due to tryptophan depletion. Multiplicity of mediators released by these tumors complicates identification of factors responsible for heart lesions. Correlation between high plasma serotonin levels and valvular abnormalities detected by cardiac catheterization and echocardiography has been reported. Thus, serotonin overproduction was proposed to be responsible for cardiac valvular disease in patients with carcinoid tumors (Robiolio, et al., 1995).

In Sprague-Dawley rats, a model of valvulopathy induced by serotonin injection has been developed (Elangbam, et al., 2008), resulting in defects of mitral and aortic valves characterized by nodular thickening of leaflets with an overload of glycosaminoglycans, without fibrosis or inflammatory infiltrate. Initial lesions are neither ischemic nor necrotic but originate from activation of cells, which secrete glycosaminoglycans, responsible for initial valve thickening. Administration of serotonin at lower dose but over a longer period (1 subcutaneous injection/day for 3 months, $50 \mathrm{mg} / \mathrm{kg} / 3$ days and then $20 \mathrm{mg} / \mathrm{kg} /$ day) causes a massive increase in serotonin concentration in whole blood with saturation of platelet storage capacities. As a consequence, plasma free serotonin is increased (Gustafsson, et al., 2005), and valve thickening and shortening mainly at aortic sigmoid level. Pathological tissue is made of myofibroblasts enclosed in a collagen matrix. It is important to note that authors also observed sub-endocardial plaques outside valvular regions. In this case, collagen matrix assumes a more myxoid appearance.

In total, carcinoid plaques evolve in two phases. A first phase is activation of proteoglycans secretion by fibroblasts. This local production of proteoglycans promotes recruitment of growth and mitogenic factors as observed for ventricular fibroblasts (Prante, et al., 2007). In a second phase, myofibroblasts recruited by chemoattractant factors attached to matrix, will produce collagen and then retract to form myxoid lesions. This phenomenon is not restricted to human or murine native valves since in the absence of reduction in tumor endocrine secretion, patients who had valvular replacement by a pig bioprostheses developed myxoid evolution of bioprostheses (Ohri, et al., 1994; Ridker, et al., 1991).

\subsection{Pharmacological mechanisms in carcinoid heart \\ 6.4.1 5- $\mathrm{HT}_{2}$ receptor expression}

The hypothesis for a role played by serotonin in carcinoid plaques has led several authors to characterize expression of serotonin receptors in cardiac valve cells (Elangbam, 2010). This expression varies according to species, but 5- $\mathrm{HT}_{4}, 5-\mathrm{HT}_{2 \mathrm{~A}}$ and $5-\mathrm{HT}_{2 \mathrm{~B}}$ receptors are regularly found in monkeys, mice, rats and humans. Serotonin has mild proliferative effects on human valvular fibroblasts (Rajamannan, et al., 2001). Proliferative effects of serotonin were prevented by methiothepin but not by ketanserin, and authors hypothesized that $5-\mathrm{HT}_{1 \mathrm{~B}}$ receptors were involved in this response. In fact, these two antagonists have similar affinities for human 5- $\mathrm{HT}_{1 \mathrm{~B}}$ receptors (respectively 0.1 and $3 \mathrm{nM}$, PSPD $\mathrm{Ki}$ Database, 
http://pspd.med.unc.edu/) as for $5-\mathrm{HT}_{2 \mathrm{~A}}$ receptors (respectively 1 and $2 \mathrm{nM}$ ). The only difference between these two molecules lies in their affinity for 5- $\mathrm{HT}_{2 \mathrm{~B}}$ receptors since methiothepin has a $\mathrm{Ki}$ of $0.6 \mathrm{nM}$, and ketanserin over $300 \mathrm{nM}$ for $5-\mathrm{HT}_{2 \mathrm{~B}}$ receptors, which may thus be involved. In rodents, mRNAs for $5-\mathrm{HT}_{2 \mathrm{~B}}$ and $5-\mathrm{HT}_{2 \mathrm{~A}}$ receptors are expressed in valvular cells unlike 5- $\mathrm{HT}_{2 \mathrm{C}}$ receptors, thus excluding a role for 5- $\mathrm{HT}_{2 \mathrm{C}}$ receptors (Droogmans, et al., 2007b). In mitral, tricuspid, aortic valves, and healthy adult human lung, immunostaining techniques revealed the presence of $5-\mathrm{HT}_{2 \mathrm{~B}}$ receptors on interstitial and endothelial cells (Elangbam, et al., 2005).

\subsubsection{5-HT 2 receptor ligand}

The search for serotonergic receptors involved in carcinoid heart disease was largely directed by the similarity between valvular heart damage associated with methysergide and carcinoid heart valve disease (Hendrikx, et al., 1996). Among these substances, ergotamine, methysergide and its metabolite, methylergonovine, have in common a fairly high affinity for human 5- $\mathrm{HT}_{2 \mathrm{~B}}$ receptors, while being partial or full agonists (Rothman, et al., 2000). Norfenfluramine is the active metabolite of dexfenfluramine, which was used as an anorectic compound, and is suspected to cause heart valve disease similar to that observed in carcinoid syndrome (Fitzgerald, et al., 2000). Norfenfluramine, has a high affinity for 5- $\mathrm{HT}_{2 \mathrm{~B}}$ receptors and stimulates mitogenesis (Connolly, et al., 1997). In support, MDMA (Ecstasy), and its metabolite MDA, induce, as well, a proliferation of human valvular interstitial cells by activating 5- $\mathrm{HT}_{2 \mathrm{~B}}$ receptors (Setola, et al., 2003) associated with the onset of valvulopathies (Droogmans, et al., 2007a; Elangbam, et al., 2008). Similarly, echocardiographic and histopathological data showed that ergot derivatives, used for their agonist properties on dopaminergic receptors, may induce valvular damage similar to those observed in carcinoid syndrome (Horvath, et al., 2004). Indeed, valvular diseases are observed in Parkinson's disease patients treated with pergolide or cabergoline (Antonini \& Poewe, 2007; Roth, 2007), which are also $5-\mathrm{HT}_{2 \mathrm{~B}}$-receptor agonists, but not with lisuride or terguride, which are not (Jahnichen, et al., 2005). All these elements suggest an important role for 5- $\mathrm{HT}_{2 \mathrm{~B}}$ receptors. A simultaneous mitral bioprostheses hypertrophic scaring and native aortic valve fibrosis was recently reported during benfluorex therapy in a 40-year-old woman. Bioprostheses and aortic valves exhibited similar histopathological lesions. Thickening and plaque deposits made by smooth muscle $\alpha$-actin- and vimentin-positive cells in a glycosaminoglycan matrix were observed supporting that $5-\mathrm{HT}_{2 \mathrm{~B}}$ receptors activated by norfenfluramine (also metabolite of benfluorex) may trigger the development of drug-induced native valve degeneration, and also of valve prostheses (Ayme-Dietrich, et al., 2012). Regarding valvular damage due to serotonergic agonists, pharmacological prevention by selective $5-\mathrm{HT}_{2 \mathrm{~B}}$-receptor antagonist has never been published. Nevertheless, all data are in favor of an involvement of these receptors. Drugs already used as antipsychotics (clozapine, olanzapine) or antihistamines (cyproheptadine) are antagonists with high affinity for 5- $\mathrm{HT}_{2 \mathrm{~B}}$ receptors. Interestingly, Parkinsonians experiencing hallucinations can nowadays be treated with recently FDA approved 5- $\mathrm{HT}_{2}$ antagonist pimavanserin (Fox, 2014).

\subsubsection{Valvulopathy, a reinitialisation of embryonic valve development?}

Most adult valvular lesions are reminiscent of embryonic phases of valvulogenesis, involving epithelial-mesenchymal transition (EMT) and proliferative expansion with accumulation of extracellular matrix and myofibroblasts (mesenchymal interstitial cells) (Shworak, 2004). Inducers of EMT during valvulogenesis include vascular endothelium growth factor (VEGF), transforming growth factor beta 1 (TGF- $\beta 1)$, and Wnt/ $\beta$-catenin, which are regulated in a spatiotemporal manner. In EMT, TGF- $\beta 1$ can induce trans-differentiation of endothelial cells into myofibroblasts. Serotonin may participate in this transition during carcinoid valvulopathy 
since TGF- $\beta 1$ is expressed by interstitial cells (Shworak, 2004), and serotonin can increase expression of TGF- $\beta 1$ as well as collagen biosynthesis. Overexpression of a constitutively active mutant of $\mathrm{G} \alpha \mathrm{q}$ protein (Q209L-G $\alpha \mathrm{q})$ increases phospholipase C activity and TGF- $\beta$ expression (Jian, et al., 2002). Serotonin-associated valvulopathies may thus depend on activation of serotonin $\mathrm{Gq}$ coupled receptors, 5- $\mathrm{HT}_{2}$ receptors (Xu, et al., 2002). 5- $\mathrm{HT}_{2 \mathrm{~B}}$ receptor expression is increased in valvulopathies (Elangbam, 2010), although a role for 5$\mathrm{HT}_{2 \mathrm{~A}}$ receptor cannot be excluded (Xu, et al., 2002). A recent work has shown that SERT was down regulated in parallel to $5-\mathrm{HT}_{2 \mathrm{~B}}$ receptor overexpression in valvular fibrosis model induced by high doses of serotonin in rats (Elangbam, 2010), and SERT expression has been found at valvular level during development (Pavone, et al., 2008).

Recent evidence suggests that degenerative valvular disease may be mediated by developmental pathways including bone morphogenic protein (BMP), Wnt and Notch signaling, nitric oxide (NO), and angiotensin II (Orton, et al., 2012). Wnt2 acts as an angiogenic factor for endothelium in-vitro and in-vivo whose target genes undergo complex regulation by tissue microenvironment. By gene profiling, 5- $\mathrm{HT}_{2 \mathrm{~B}} \mathrm{mRNA}$ was identified as a down-regulated target gene of Wnt2 signaling in HUVEC (Klein, et al., 2009). Existence of valve interstitial cells derived at different times and from different origins (i.e., embryonic epicardium and endocardial cushions or adult bone marrow) raises interesting possibility that populations of fibroblasts are functionally different and, thus, differ in their susceptibility to and/or participation in fibrotic pathological processes (Visconti, et al., 2006).

\subsubsection{Valvulopathy and bone marrow mobilization of endothelial progenitors}

In fact, a rapid migration of bone-marrow (BM)-derived cells in mitral valve tissue was described after fluorescent cells engraftment in wild-type mice (Visconti et al., 2006). These cells could constitute part of a so-called "reservoir" of endothelial progenitors that would then transdifferentiate via the general process of endothelial to mesenchymal transition. Using pharmacological and transgenic mice experiments, the contribution of 5- $\mathrm{HT}_{2 \mathrm{~B}}$ receptors in drug-induced valvulopathy was shown to result from endothelial progenitors mobilization (Ayme-Dietrich, et al., 2017). Chronically activated 5-HT $\mathrm{H}_{2 \mathrm{~B}}$ receptors by nordexfenfluramine in mice mimick early steps of mitral valve remodeling attested by increased valve thickness, and cell density in a thick extracellular matrix. Lesions can be totally prevented by inhibition of both $5-\mathrm{HT}_{2 \mathrm{~A}}$ and 5- $\mathrm{HT}_{2 \mathrm{~B}}$ receptors either by antagonists or in transgenic $\mathrm{Htr}_{2 B^{-/}}$, or $\mathrm{Htr}_{2 \mathrm{~A} / 2 \mathrm{~B}^{-}}$ ${ }^{-}$mice. Surprisingly, valve lesions are mainly formed by numerous non-proliferative CD34 ${ }^{+}$ endothelial progenitors. These progenitors originate from bone marrow as revealed by bone marrow transplantation. Initial steps of mitral valve remodeling involve bone marrow derived $\mathrm{CD} 34^{+} \mathrm{CD} 31^{+}$cells mobilization by $5-\mathrm{HT}_{2 \mathrm{~B}}$-receptor stimulation. Moreover, the analysis of human mitral valve prolapse, showing spontaneous degenerative lesions highlights the presence of non-proliferating $\mathrm{CD} 34^{+} / \mathrm{CD} 309^{+} / \mathrm{NOS}^{+}$endothelial progenitors expressing 5$\mathrm{HT}_{2 \mathrm{~B}}$ receptor (Ayme-Dietrich, et al., 2017). Therefore, a contribution of bone marrow derived endothelial progenitor cells is required for valve tissue remodeling in mice and in human valvular heart disease.

\section{Serotonin in cardiac hypertrophy and failure}

HF is defined as a clinical syndrome where the heart fails to meet systemic oxygen demands. Patients complain of breathing difficulties initially upon strong physical exercise. Breathing difficulties become progressively worsen, and finally manifest as a resting dyspnea. In developed countries, the two main origins of this condition are chronic left ventricular dysfunction due to post MI and primary dilated cardiomyopathy. Progressive aggravation of the disease is partly due to initial injury but also to a continuous process affecting both 
geometrical and histological structure of myocardium. This continuous phenomenon, independent of triggering factors, is called "remodeling". Medical treatments were initially aimed at improving hemodynamics and contractility by reducing filling pressures. A major step forward was made when chronic treatment focused on remodeling instead of cardiac contractility. Thus, basic treatment must combine drugs that reduce the activity of reninangiotensin-aldosterone system (angiotensin-converting enzyme inhibitors, angiotensin-AT1 receptor antagonists and aldosterone-receptor blockers) and sympathetic system ( $\beta$-blockers). Unfortunately, despite this therapeutic revolution, many patients cannot benefit from optimal doses of these treatments due to hemodynamic and/or metabolic side effects. Research is now focusing on identification of new therapeutic targets. Numerous studies have focused on interactions between cardiac extracellular matrix cells and cardiomyocytes. In the following section, we will try to clarify functions of serotonin in HF, both in terms of hemodynamics and remodeling.

Two types of cardiac hypertrophy can schematically be identified:

- The so-called physiological hypertrophy is seen in athletes who practice chronic physical exercise. This hypertrophic heart is also called "athletes heart" and corresponds to an adaptive response, which is beneficial to cardiovascular system. In endurance sports, cardiac hypertrophy is of eccentric type resulting in an increase in ventricular diameters. It is usually observed in cyclists and long-distance runners and swimmers (Castanheira, et al., 2017). Increasing diameters increases filling volumes and is usually associated with a slower heart rate, which, in turn, contributes to an increase of diastolic ventricular filling time. In sports carried out for short durations but at very high intensity, cardiac hypertrophy is concentric, mainly involving increased wall thicknesses. These two types of physiological cardiac hypertrophy share in common to regress spontaneously when practice is stopped.

- The second type of cardiac hypertrophy, called pathological hypertrophy, involves mechanisms different from physiological hypertrophy. It is part of a global phenomenon of heart remodeling that results in damage to shape (geometric remodeling), structure (histological remodeling), associated with alterations in gene expression profile. This remodeling is a complex phenomenon that takes place after pathologies such as MI or hypertension. In this context, cardiac hypertrophy is initially a compensation mechanism, which, at short term, allows normal cardiac function to be maintained, especially when parietal stress is increased. This remodeling does not regress spontaneously and contributes to irremediable evolution towards chronic ventricular dysfunction. At the cellular level, it is characterized by an increase in size and number of cardiomyocyte sarcomeres and by hyperplasia of cardiac extracellular matrix resulting from fibroblast proliferation and collagen deposit. This hypertrophy is under the control of large, and still unknown number, of neuroendocrine and neurohumoral factors. However, activation of sympathetic and renin-angiotensin-aldosterone systems are cornerstones in remodeling processes acting both at cardiomyocytes and extracellular cell matrix.

Since the Framingham study, it is known that pathological cardiac hypertrophy constitutes an independent risk factor for morbimortality, whatever the trigger. During the last twenty years it was found that cardiac hypertrophy is strongly correlated with high mortality rate in HF and is associated with phenomena such as cardiomyocyte apoptosis. Relative decrease in oxygen uptake in myocardium as well as heart rhythm disorders can lead to sudden death. In hypertension, reduction of blood pressure alone is not sufficient for hypertrophy to regress. For this reason, treatments targeting remodeling have been selected. Beta-blockers, angiotensin-converting enzyme inhibitors and AT-1 receptor antagonists can prevent or reverse cardiac hypertrophy, while influencing blood pressure. Nevertheless, long-term use of 
these molecules raises problems of hemodynamic or nephrological tolerance, leaving place in therapeutic arsenal for more active and/or better-tolerated compounds.

\subsection{Serotonin and its receptors in cardiac remodeling}

Both 5- $\mathrm{HT}_{2 \mathrm{~A}}$ and 5- $\mathrm{HT}_{2 \mathrm{~B}}$ receptors expressed by cardiomyocyte are implicated in cardiac hypertrophy and failure. The $5-\mathrm{HT}_{2 \mathrm{~A}}$ receptor activation triggers positive inotropic responses (Brattelid, et al., 2007). Noteworthy, despite a similar coupling, 5- $\mathrm{HT}_{2 \mathrm{~B}}$-receptor stimulation does not elicit any contractile response. A cardioprotective role of 5-HT $2 \mathrm{~A}$ receptor blockade was also suggested by Blasco-Fontecilla et al. (2010). These authors emphasized that atypical antipsychotic drugs could reduce the risk of cardiovascular events in schizophrenia. In fact, cardiovascular risk can be increased in these patients due to cigarette smoking, metabolic disorders and/or cardiac arrhythmias linked to QT prolongation induced by antipsychotics. Independently of lifestyle, some of these negative effects can be promoted by antipsychotics themselves, but interestingly, Tiihonen et al. (2009) suggested that long term exposure to antipsychotics could reduce overall cardiovascular mortality, the best profile being obtained for antipsychotic drugs with the highest $5-\mathrm{HT}_{2}$ receptor affinity i.e. clozapine, quetiapine, olanzapine and thioridazine. It is quite difficult to identify a mechanism in such epidemiological studies, but a reduction of platelet aggregation and thrombus formation combined with a limitation of coronary spasms, both linked to serotonin-mediated $5-\mathrm{HT}_{2 \mathrm{~A}}$ receptor activation, could contribute to cardiovascular protection in these patients.

Another role of cardiac 5- $\mathrm{HT}_{2}$ receptors is myocardial hypertrophy. Although genetic studies failed to show genetic polymorphisms in $5-\mathrm{HT}_{2 \mathrm{~A}}$-receptor gene in patients with hypertrophic cardiomyopathy of genetic origin or due to hypertension, expression of this receptor is increased in cardiac hypertrophy and its pharmacological blockade can prevent development of cardiac hypertrophy induced by transverse aortic constriction in mice (Lairez, et al., 2013). Caveolin-3 (Mialet-Perez, et al., 2012) and calcineurin/NFAT (Vindis, et al., 2010) pathways could be involved in these regulations giving to serotonin a pathophysiological role in cardiac hypertrophy. In human adults, 5- $\mathrm{HT}_{2 \mathrm{~B}}$ receptors are also overexpressed in heart of patients with congestive HF, this overexpression being positively correlated with cytokine and norepinephrine plasma levels (Jaffre, et al., 2009). Serotonin plasma levels are also increased in patients with HF and in animal studies with cardiac hypertrophy induced by aortic constriction. These findings may indicate that serotonin induces cardiac hypertrophy or $\mathrm{HF}$ through $5-\mathrm{HT}_{2 \mathrm{~B}}$ receptors. The $5-\mathrm{HT}_{2 \mathrm{~B}}$ receptor may be involved in cardiac hypertrophy by a direct action on cardiac myocytes. After two weeks of aortic banding in rats, mRNA and protein expression of 5- $\mathrm{HT}_{2 \mathrm{~B}}$ receptors increased significantly. The 5- $\mathrm{HT}_{2 \mathrm{~B} / 2 \mathrm{C}}$ receptor antagonist, SB215505, significantly reduced the increase in heart weight, heart wall thickness, left ventricular mass and expression of brain natriuretic peptide (BNP) but did not attenuate up-regulation of 5- $\mathrm{HT}_{2 \mathrm{~B}}$ receptor protein expression (Jaffre, et al., 2009). Following in-vitro mechanical stretch of cardiomyocytes and incubation with serotonin, levels of $5-\mathrm{HT}_{2 \mathrm{~B}}$ receptors and $\mathrm{BNP}$ protein increased time-dependently. When transfected with specific siRNA for $5-\mathrm{HT}_{2 \mathrm{~B}}$ receptors in cardiomyocytes, the increase of NF- $\kappa \mathrm{B}$ translocation and BNP protein induced by serotonin incubation plus mechanical stretch was reversed (Liang, et al., 2006).

By mimicking sympathetic stimulation in vivo, mice knockout for 5- $\mathrm{HT}_{2 \mathrm{~B}}$ receptors did not develop isoproterenol-induced left ventricular hypertrophy (Jaffré, et al., 2004). Exact cardiac cell type(s) expressing 5- $\mathrm{HT}_{2 \mathrm{~B}}$ receptors (cardiomyocytes versus non-cardiomyocytes) involved in this pathological heart hypertrophy was addressed in vivo: mice expressing 5$\mathrm{HT}_{2 \mathrm{~B}}$ receptors solely in cardiomyocytes, like global 5- $\mathrm{HT}_{2 \mathrm{~B}}$ receptor-null mice, are resistant to isoproterenol-induced cardiac hypertrophy and dysfunction, as well as to isoproterenolinduced increases in plasma cytokine levels (Jaffre, et al., 2009) suggesting a non- 
cardiomyocyte effect. In primary culture of cardiac fibroblasts, angiotensin II and isoproterenol stimulated $\mathrm{NAD}(\mathrm{P}) \mathrm{H}$ oxidase activity that was prevented by $\mathrm{SB} 215505$. The 5$\mathrm{HT}_{2 \mathrm{~B}}$ receptor blockade prevented increase in cardiac superoxide generation and hypertrophy in two models of cardiac hypertrophy, i.e., angiotensin II and isoproterenol infusions in mice (Monassier, et al., 2008). A functional interaction between AT1 and 5- $\mathrm{HT}_{2 \mathrm{~B}}$ receptors via a transinhibition mechanism that may involve heterodimeric receptor complexes was shown to trigger cytokine release in cardiac fibroblasts (Jaffre, et al., 2009) and could be a new therapeutic target.

Involvement of 5- $\mathrm{HT}_{2 \mathrm{~B}}$ receptors was reported in generation of apoptotic events associated with cardiac remodeling during adrenergic stimulation (Bai, et al., 2010). Based on these data, effects of chronic 5- $\mathrm{HT}_{2 \mathrm{~B}}$-receptor blockade by the selective antagonist, RS127445, were investigated in spontaneously hypertensive rats showing a left ventricular hypertrophy combined with diastolic dysfunction and an apparently normal ejection fraction (Ayme-Dietrich, et al., 2015; Marzak, et al., 2014). In this model, the 5- $\mathrm{HT}_{2 \mathrm{~B}}$ receptor is overexpressed in left ventricle but the antagonist did not improve cardiac function and hypertrophy. An increase in subendocardial ventricular fibrosis was reproduced by serotonin injections in wildtype and amplified in $\mathrm{Htr}_{2} \mathrm{~b}^{-/}$animals. Therefore, in hypertensive cardiomyopathy, 5- $\mathrm{HT}_{2 \mathrm{~B}}$ receptors could also be associated to cardioprotection through an endothelial mediated coronary vasodilatation (Ayme-Dietrich, et al., 2015).

These data revealed a dual role of $5-\mathrm{HT}_{2 \mathrm{~A} / 2 \mathrm{~B}}$ receptors on both cardiomyocytes and cardiac fibroblasts in regulating cardiac hypertrophy in-vivo in addition to vascular effects.

\subsection{Serotonin and its receptors in cardiac hemodynamics and failure}

Sympathetic nervous system regulates myocardium contractility by activating $\beta$-adrenergic receptors coupled to $\mathrm{Gs}$ and to $\mathrm{Gq}$ proteins such as $\beta 2$ - and $\alpha 1$-adrenergic receptors. The former provides a rapid control of contractility by causing an increase in cytoplasmic calcium concentration, whereas the latter tends to sensitize contractile apparatus to calcium. At an energetical point of view, this latter route is certainly more economic. One can draw a parallel between these effects and serotonergic receptors. Indeed, two major serotonin receptor populations in myocardium are $5-\mathrm{HT}_{2}(2 \mathrm{~A}$ and $2 \mathrm{~B})$ and $5-\mathrm{HT}_{4}$, respectively, coupled to $\mathrm{Gq}$ and Gs proteins (Levy, et al., 2008).

$5-\mathrm{HT}_{4}$ receptors are expressed in atrial and ventricular myocardium with variations between species. Indeed, 5-HT 4 receptors were detected only in normal adult heart in humans (Bach, et al., 2001) and pig (Brattelid, et al., 2004) but not in rat, rabbit or mouse. However, its expression can vary widely in pathological situations. In fact, 5-HT 4 -receptor expression increases in diseased human ventricular myocardium, and in the same situation it appears in rats (Qvigstad, et al., 2005). In normal conditions, stimulation of this receptor does not induce significant effects because of cAMP degradation by phosphodiesterases (Kaumann \& Levy, 2006). On the other hand, in the presence of a phosphodiesterase inhibitor, an effect of serotonin through $5-\mathrm{HT}_{4}$ receptors was demonstrated, leading to increased contractility, relaxation and sometimes arrhythmias (Levy, et al., 2008). These actions are redolent of catecholamines effects on $\beta$-adrenergic receptors. HF seems to induce a chronic reduction in phosphodiesterase activity in cell compartments in which $5-\mathrm{HT}_{4}$ receptors are expressed. This regulation could explain why HF spontaneously reveals their function. In rats with failing hearts, identical concentrations of isoproterenol and serotonin produce similar increases in contractility. The serotonin effects are prevented by GR113808, a high-affinity 5-HT antagonist (Qvigstad, et al., 2005).

In diseased myocardium, an increase in expression of $5-\mathrm{HT}_{2 \mathrm{~A}}$ receptors has also been observed. Increased contractility caused by serotonin is partially prevented by ketanserin, a 5$\mathrm{HT}_{2 \mathrm{~A}}$ receptor antagonist (Qvigstad, et al., 2005). A recent study reported overexpression of 
5- $\mathrm{HT}_{2 \mathrm{~A}}$ in pathological human myocardium, opening a possible role in contractile support of failing myocardium (Brattelid, et al., 2004). Molecular mechanisms leading to inotropic effects due to stimulation of 5- $\mathrm{HT}_{2 \mathrm{~A}}$ receptors are still imperfectly known but their activation seems to lead to a triphasic effect on ventricular contractility: a transient increase followed by a decrease and then a long-lasting increase. The latter appears several minutes after application of agonist and comes from induction of myosin light chain phosphorylation (MLC-2) as by $\alpha_{1}$-adrenergic-receptor activation (Brattelid, et al., 2007). Recently, a selective 5-HT $2 \mathrm{~A}$-receptor antagonist, M100907, was tested on cardiac hypertrophy induced by transverse aortic constriction (TAC). The 5- $\mathrm{HT}_{2 \mathrm{~A}}-$ receptor expression was transiently increased after TAC in cardiomyocytes. Selective blockade of 5-HT $2 \mathrm{~A}$ receptors prevented cardiac hypertrophy. Thus, selective blockade of $5-\mathrm{HT}_{2 \mathrm{~A}}$ receptors has beneficial effect in development of cardiac hypertrophy through inhibition of CamKII/HDAC4 pathways (Lairez, et al., 2013).

Overexpression (or reexpression) of serotonergic receptors in pathological situations is important since it contrasts to what is known for adrenergic receptors. In particular, positive inotropic responses do not desensitize with time. It could correspond to re-initiation of an embryonic expression program. In fetal and neonatal rat cardiomyocytes, both 5- $\mathrm{HT}_{4} \mathrm{mRNA}$ expression and functional responses were highest at postnatal day-3 and decreased gradually to day-5, with a further decrease to adult levels. In HF, receptor mRNA levels and functional responses reappear, but to lower levels than in fetal ventricle. $5-\mathrm{HT}_{2 \mathrm{~A}}$ and $5-\mathrm{HT}_{2 \mathrm{~B}}$ receptor mRNA levels increases to a maximum immediately after birth, but only 5- $\mathrm{HT}_{2 \mathrm{~A}}$ receptors mediate a positive inotropic response. The $5-\mathrm{HT}_{4}$ receptor is representative of a fetal cardiac gene program, functional in late fetal development and reactivated in HF (Brattelid, et al., 2012). The question is whether this inotropic compensation occurs when contractile adrenergic responses are strongly desensitized or occurs in early phases of ventricular remodeling. This issue was addressed in a work by Brattelid et al., (2007) who studied inotropic responses due to serotonin in rats after pressure overload induced by aortic banding. These animals initially demonstrated a hypertrophic cardiopathy, which evolves towards dilation and decompensation. Clearly, expression of 5- $\mathrm{HT}_{4}$ receptor mRNA increases from hypertrophic stage to HF. This expression correlates with strong inotropic responses following application of serotonin. Expression of 5- $\mathrm{HT}_{2 \mathrm{~A}}$ receptor mRNA also increases during hypertrophy, but does not appear to be modified at failing stage. Inotropic response associated with this receptor does not seem to correlate with expression level, supporting intracellular regulation mechanisms.

Both $\beta_{1}$-adrenergic and $5-\mathrm{HT}_{4}$ receptors follow similar coupling pathways and functions. Knowing effectiveness of $\beta$-blockers in $\mathrm{HF}$, it was tempting to explore putative effects of $5-\mathrm{HT}_{4}$ receptor antagonists in this pathological condition. This work has been carried out in animals and more recently in humans. Rats were divided into two treatment groups, three days after MI induced by coronary ligation (Birkeland, et al., 2007). The first group was treated with placebo for six weeks while the second one received piboserod, a 5$\mathrm{HT}_{4}$-receptor antagonist at a dose of $0.5 \mathrm{mg} / \mathrm{kg} / \mathrm{day}$. Piboserod significantly and slightly improved cardiac function and remodeling. At the same time, the same molecule was evaluated in a randomized trial including 137 patients with symptomatic cardiac insufficiency receiving optimized medical treatment (Kjekshus, et al., 2009). At baseline, patients had a left ventricular ejection fraction lower than 35\%. 70 patients received placebo while 67 were treated with progressively titrated piboserod: $20 \mathrm{mg} /$ day the first two weeks and $40 \mathrm{mg} /$ day the next two, before rising to $80 \mathrm{mg} /$ day for the rest of the trial, i.e. 24 weeks. Primary endpoint was left ventricular ejection fraction measured by nuclear magnetic resonance imaging and adverse reactions. This study showed a modest improvement in left ventricular ejection fraction and a small reduction in ventricular dilation. An increase in blood pressure of 
$4.4 \mathrm{mmHg}$ compared to placebo argued in favor of hemodynamic improvement. All these results showed a positive effect of piboserod. In this study, activities of this compound could have been lowered by treatment with $\beta$-blockers. In a subgroup analysis, patients without these drugs showed a superior response to piboserod. Nevertheless, in both rats and humans, blockade of $5-\mathrm{HT}_{4}$ receptors appears to have little effect on ventricular remodeling. Everything is as if this receptor had only a role of hemodynamic regulation and little involvement in remodeling phenomena.

\subsection{Atrial fibrillation and $5-\mathrm{HT}_{4}$ receptors.}

Atrial fibrillation is a disease whose prevalence is increasing with age. Increasing risk of thrombotic and embolic events also contributes to limit diastolic left ventricular filling in patients with cardiac insufficiency. It is probably unnecessary to turn fibrillation to sinus rhythm in all patients, especially when ventricular functions are good, but sometimes, because of poor hemodynamic tolerance, this correction is necessary and there is a therapeutic place for drugs preventing recurrence. Both subtypes of $5-\mathrm{HT}_{4}$ receptors $\left(5-\mathrm{HT}_{4 \mathrm{a}}\right.$ and $\left.5-\mathrm{HT}_{4 \mathrm{~b}}\right)$ are expressed by atrial myocytes, including in humans, and have been suspected to contribute to genesis and maintenance of atrial fibrillation. In this structure, $5-\mathrm{HT}_{4}$ receptor activates adenylyl cyclase via stimulation of Gs leading to stimulation of L-type calcium channels (Castro, et al., 2005). Nevertheless, to date, no study has demonstrated efficacy of 5-HT4 antagonist in atrial fibrillation.

\section{Vascular responses to serotonin}

\subsection{Hypertension}

In arterial wall, endothelial cells express $5-\mathrm{HT}_{1 \mathrm{~B}}, 5-\mathrm{HT}_{2 \mathrm{~B}}$ and $5-\mathrm{HT}_{4}$ receptors, whereas smooth muscle cells express $5-\mathrm{HT}_{1 \mathrm{~B}}, 5-\mathrm{HT}_{2 \mathrm{~A}}, 5-\mathrm{HT}_{7}$ receptors and in some cases $5-\mathrm{HT}_{2 \mathrm{~B}}$. This expression pattern suggests that serotonin plays a complex role in regulating vasomotor tone (Ullmer, et al., 1995). Indeed, receptors expressed on endothelial cells can induce vasodilation while stimulation by serotonin of smooth muscle cells elicits vasoconstriction. The contribution of serotonergic receptors in blood pressure regulation is well studied (Watts, et al., 2012). 5- $\mathrm{HT}_{2 \mathrm{~A}}$ receptors are mainly responsible for contraction of large arteries as opposed to veins that contract following 5- $\mathrm{HT}_{1 \mathrm{~B}}$-receptor stimulation (Linder, et al., 2008). By contrast, not all blood vessels can relax to 5-HT; in jugular vein and pulmonary artery and coronary arteries, serotonin causes relaxation through activation of 5- $\mathrm{HT}_{2 \mathrm{~B}}$ and $5-\mathrm{HT}_{7}$ receptors (Watts, et al., 2012). Recent work confirmed that the superior mesenteric vein possesses a highly sensitive $5-\mathrm{HT}_{7}$ receptor that mediates venous relaxation without requiring blockade of contractile receptors, not excluding the potential involvement of the 5-HT $2 \mathrm{~B}$ receptor (Watts, et al., 2015).

The vasoconstrictor effects of serotonin are much greater in experimental or genetic models of hypertension than in animals with normal blood pressure (Watts, et al., 2012). These studies raised the question of serotonin involvement in pathophysiology of hypertension. Smooth muscle from rats, which became hypertensive by a combination of deoxycorticosterone acetate and salt (DOCA/salt) are more responsive to serotonin. This increase is attributed to a shift in receptor population expressed by large arteries. Indeed, if 5$\mathrm{HT}_{1 \mathrm{~B}}$ receptor agonists do not contract aorta and mesenteric artery of normotensive rats, a contribution of these receptors to mesenteric artery appears in hypertensive animals (Banes, et al., 2001). This phenomenon has also been observed for 5- $\mathrm{HT}_{2 \mathrm{~B}}$ receptors. More precisely, Watts et al. (1996; 1995) provided pharmacological and molecular evidence showing that 5$\mathrm{HT}_{2 \mathrm{~A}}$ (ketanserine-sensitive) receptors are primarily responsible for contraction of arteries of normotensive rats, whereas $5-\mathrm{HT}_{2 \mathrm{~B}}$ receptors (relatively insensitive to ketanserin) are 
primarily responsible for contraction of DOCA/salt arteries of rats. This switch is crucial because serotonin has higher affinity for $5-\mathrm{HT}_{2 \mathrm{~B}}$ than for $5-\mathrm{HT}_{2 \mathrm{~A}}$ receptors and therefore, a lower concentration of serotonin allows complete activation of 5- $\mathrm{HT}_{2 \mathrm{~B}}$ receptors. In-vivo, the same group showed that increased activation of 5- $\mathrm{HT}_{2 \mathrm{~B}}$ receptors is responsible for hypertension in DOCA/salt rats because the antagonist LY-272015 (5- $\mathrm{HT}_{2 \mathrm{~B}}$-selective) reduces blood pressure of these animals (Watts \& Fink, 1999).

Fenfluramine is an anorectic compound whose active metabolite, norfenfluramine, causes vasoconstriction and an increase in arterial pressure in rats by activating $5-\mathrm{HT}_{2 \mathrm{~A}}$ receptors. This compound has higher affinity for $5-\mathrm{HT}_{2 \mathrm{~B}}$ receptors whose level of expression is increased in hypertensive DOCA/salt rats. Thus, norfenfluramine increases more blood pressure in hypertensive animals. This effect would be due to an action in small arteries because, in aorta of normal or hypertensive rats, contraction induced by norfenfluramine involves $5-\mathrm{HT}_{2 \mathrm{~A}}$ but not $5-\mathrm{HT}_{2 \mathrm{~B}}$ receptors. $5-\mathrm{HT}_{2 \mathrm{~A}}$ and $5-\mathrm{HT}_{2 \mathrm{~B}}$ receptors therefore seem to play complementary roles depending on vascular bed and/or physiological state of vessels (Watts, et al., 2012). This experiment confirms clinical data, which showed that ketanserin lowered blood pressure by a mechanism mainly involving blocking of $\alpha_{1}$-adrenergic instead of serotonin receptors.

In summary, serotonin weakly contributes to basal vasomotor tone but its contribution is reinforced in hypertension mainly due to a transition in expression of receptors with higher affinity to serotonin $\left(5-\mathrm{HT}_{2 \mathrm{~A}}\right.$ to $\left.5-\mathrm{HT}_{2 \mathrm{~B}}\right)$. On the other hand, the origin of vascular serotonin is not clear. It could come from blood platelets or from a nervous release as we mentioned above in heart.

\subsection{Coronaropathy and ischemic preconditioning}

Unstable angina and MI are pathological situations where vasomotor disorders of coronary arteries coexist with platelet activation and myocardial suffering. In such situations, activated platelets release their stock of serotonin. Serotonin is thus able to activate platelet $5-\mathrm{HT}_{2 \mathrm{~A}}$ receptors but also other serotonergic receptors expressed in coronary arteries and cardiomyocytes. In-vitro studies on human coronary arteries endothelial cells have shown that serotonin, by activating $5-\mathrm{HT}_{1 \mathrm{~B}}$ and $5-\mathrm{HT}_{2 \mathrm{~B}}$ receptors, is responsible for nitrites production from NO metabolism (Ishida, et al., 1998). In conscious dogs, Ergonovine, a ligand with high affinity for $5-\mathrm{HT}_{2}$ receptors, induces vasodilation followed by vasoconstriction, accompanied by an increase in coronary flow. Vasodilation depends on NO synthase (NOS) activity. Similarly, in rats, serotonin demonstrates a potent coronary vasodilator effect since it increases coronary flow in a dose-dependent manner. These effects are obtained on vessels with an intact endothelium. The presence of endothelial dysfunction or partial desendothelialization may, on the contrary, reveal a coronaro-constricting effects of serotonin released in vascular lumen (Takano, et al., 2004). These data open the possibility that interactions between activated platelets and vascular wall contribute to acute ischemic or ischemic/reperfusion lesions.

Pharmacology of serotonin receptors is complex in systemic arteries. Serotonin can elicit vasoconstriction through its interaction with $5-\mathrm{HT}_{2 \mathrm{~A}}$ receptors on vascular smooth muscle cells but also vasodilatation via a NO-dependent mechanism involving $5-\mathrm{HT}_{1 \mathrm{~B}} / 2 \mathrm{~B}$ receptors. In coronary circulation, effects of the preferential 5-HT $\mathrm{HA}_{2 \mathrm{~A}}$-receptor antagonist, sarpogrelate, were investigated in dogs after reduction of coronary blood flow $(30 \%$ of baseline flow) in anterior wall (Fujita, et al., 2004). Serotonin increases coronary flow of isolated rat heart by activating $5-\mathrm{HT}_{7}$ receptors, and this effect can be, at least partially, resistant to L-NAME (Chang Chien, et al., 2015). Sarpogrelate amplified serotonin release in myocardium and $5-\mathrm{HT}_{1 \mathrm{~B}}$ receptor-mediated dilatation by NOS. Such a mechanism was also suggested in an ischemic hindlimb model in diabetic mice where sarpogrelate restored 
perfusion through stimulation of endothelial NOS/Akt pathway involving 5-HT 1 B receptors (Iwabayashi, et al., 2012). Nevertheless, an effect in the absence of serotonin could also happen due to an inverse agonist action of the drug (Hossain, et al., 2012; Muntasir, et al., 2006). In humans, sarpogrelate given as a single $200 \mathrm{mg}$ oral administration also increased basal and maximal (adenosine triphosphate) average peak velocity of coronary blood flow in patients with coronary artery disease. Such a vasodilatation was also observed in rabbit cerebral arteries (Kawamura, et al., 2013) and experimental vein grafts (Kodama, et al., 2009). Mechanisms of sarpogrelate effects are not fully understood. An unmasking vasodilation linked to serotonin-induced $5-\mathrm{HT}_{1 \mathrm{~B}}$-receptor stimulation is a possible explanation but other mechanisms were proposed. In rats chronically treated with sarpogrelate, serotonergic stimulation involving $5-\mathrm{HT}_{7}$ and $5-\mathrm{HT}_{1 \mathrm{~B}}$ receptors counteracts pressure response elicited by sympathetic nervous system stimulation (Garcia-Pedraza, et al., 2014). This phenomenon involves smooth muscle cell hyperpolarization and COX-2 pathway. Interestingly, serotonin can induce a 5- $\mathrm{HT}_{2 \mathrm{~A}}$ receptor-mediated $\mathrm{COX}$-2-dependent prostacyclin synthesis by smooth muscle cells involving $\mathrm{PKC} / \mathrm{Src} / \mathrm{MAPK}$ pathway. This biological effect could be involved in vasodilatation via $5-\mathrm{HT}_{2 \mathrm{~A}}$ receptors because it is antagonized by sarpogrelate (Machida, et al., 2011). Therefore, in some conditions, a 5- $\mathrm{HT}_{2 \mathrm{~A}}$ receptor stimulation could sensitize smooth muscle cells towards vasodilation triggered by other serotonergic receptors.

Beside its contribution to vasomotion, 5- $\mathrm{HT}_{2 \mathrm{~A}}$ receptors also appear as key contributors to atherosclerosis and arterial wall remodeling. In rabbits fed on high cholesterol diet, sarpogrelate reduced the extent of atherosclerotic deposits in aorta in parallel to an induction of endothelial NOS (Hayashi, et al., 2003). These chronic effects combined with a reduction of serotonin- and angiotensin II-induced vascular smooth muscle cell proliferation (Sharma, et al., 2001; Watanabe, et al., 2001) could limit vascular remodeling. This effect is now clear for peripheral arterial disease in which sarpogrelate improves outcome of symptomatic patients (Ren, et al., 2013) but it remains to be demonstrated after endovascular therapy. Retrospective studies showed a reduction of major clinical endpoints such as amputation or death from any cause after endovascular therapy for critical hindlimb ischemia (Takahara, et al., 2014) and first preliminary results of a recent prospective study suggest that sarpogrelate associated to aspirin is as efficacious as sarpogrelate associated to clopidogrel for prevention of restenosis following femoropopliteal arterial stenting (Chen, et al., 2015). Reduction of neointimal hyperplasia in combination with improvement of endothelial function by sarpogrelate (Miyazaki, et al., 2007) supports a contribution of 5- $\mathrm{HT}_{2 \mathrm{~A}}$ receptors in chronic artery disease and sarpogrelate use in peripheral arterial disease.

Diabetes mellitus is a pathological situation at high risk for cardiovascular events. In experimental type 2 diabetes, serotonin increases plasma epinephrine and glucose, making rats insulin resistant. This resistance involves $5-\mathrm{HT}_{2 \mathrm{~A}}$ receptors because is prevented by sarpogrelate pretreatment (Takishita, et al., 2004). Insulin-sensitizing effect of sarpogrelate has been confirmed in diabetic patients (Kokubu, et al., 2006) and in mice when combined with PPAR- $\gamma$ agonist, pioglitazone (Iizuka, et al., 2009). High glucose promotes endothelial dysfunction and serotonin may be a key pathophysiological player in vascular complications of diabetes in context of metabolic syndrome. When rat aortic rings are incubated in the presence of a high glucose concentration, endothelium-dependent vasodilatation triggered by acetylcholine is reduced, whereas endothelium-independent dilatation induced by NO-donor is unaffected. Interestingly, sarpogrelate can restore endothelial NO production and, as a consequence NO-mediated dilatation (Sun, et al., 2011). Nevertheless, these effects were obtained at high sarpogrelate concentrations $(10 \mu \mathrm{M})$ in a culture medium in which serotonin concentration was not measured. This work emphasizes that blocking $5-\mathrm{HT}_{2 \mathrm{~A}}$ receptors could protect endothelial function in diabetic patients. In a rat model of type 1 diabetes, sarpogrelate 
reduced blood glucose and endothelial PECAM-1 overexpression, therefore limiting serotonin-induced thrombosis (Yamada, et al., 2012). Interestingly, this receptor also affects neointimal proliferation and restenosis following arterial stenting, although not expressed by endothelial cells. A paracrine mechanism involving cytokines released by smooth muscle cells or regulation of homing of circulating cells can explain some of vascular beneficial effects following $5-\mathrm{HT}_{2 \mathrm{~A}}$ receptor blockade.

Taken together, all these data argue in favor of a major contribution of $5-\mathrm{HT}_{2} \mathrm{~A}$ receptors in regulating vasomotor tone and in interactions between endothelial and smooth muscle cells trough a subtle equilibrium involving other receptors.

\subsection{Migraine}

Migraine is a syndrome that affects 15 to $18 \%$ of women and about $6 \%$ of men. It is characterized by intense, pulsatile headaches, classically unilateral and often accompanied by nausea, vomiting and photo/phonophobia. Briefly, the origin of migraine is a decrease in cerebral flow by vasoconstriction, followed by a reactive vasodilatation responsible for headache. This vasodilation is associated with release of many vasodilators such as NO and serotonin. It has long been known that serotonin receptors are involved in pathophysiology of migraine because of its strong contribution to regulation of cerebral vasomotricity (Goadsby, et al., 2002). Moreover, the use of serotonergic antimigraine drugs, in particular triptans, reveals some of mechanisms underlying this pathology. Indeed, numerous studies have shown clinical efficacy of $5-\mathrm{HT}_{1 \mathrm{~B}}$ agonists, such as sumatriptan, in migraine attack treatment (Ferrari, 1998). Triptans act by producing a cerebral vasoconstriction and also at sensory trigeminal ganglia. Thus, anti-migraine compounds, such as dihydroergotamine and triptans, in addition to their vascular action, prevent activation of trigeminal-vascular complex and release of CGRP ("calcitonin gene-related peptide ") associated thereto (Buzzi, et al., 1991; Hoskin, et al., 1996). They also prevent possible generation of retrograde nerve impulses (axon reflex) in nociceptive circuits in response to local meningeal excitation. Overall, this dual action, both vascular and neuronal, through stimulation of serotonin $5-\mathrm{HT}_{1 \mathrm{~B}}$ receptors, most likely accounts for efficacy of these drugs in stopping migraine attacks (Goadsby, et al., 2002).

Ergotamine, dihydroergotamine, methysergide and its metabolite, methylergonovine, are 5-HT $\mathrm{H}_{1}$ receptor antagonists but have also high affinity for 5- $\mathrm{HT}_{2}$ receptors (Kursar, et al., 1994). Their preventive effects of migraine may thus result from 5 - $\mathrm{HT}_{2 \mathrm{~B}}$-receptor blockade (Kalkman, 1994). 5- $\mathrm{HT}_{2 \mathrm{~B}}$ receptors are expressed by endothelial cells of meningeal vessels. Their activation induces relaxation by synthesis of NO in cerebral arteries and jugular vein and concomitant activation of sensory trigeminovascular afferents (Johnson, et al., 2003; Schmuck, et al., 1996). In addition, a recent genetic study identified 5- $\mathrm{HT}_{2 \mathrm{~B}}$ receptors as a susceptibility gene to migraine (Corominas, et al., 2010).

\subsection{Pulmonary arterial hypertension (PAH)}

$\mathrm{PAH}$ is a pathology in which a progressive increase in pulmonary arterial pressure causes right ventricular overload, dysfunction, hypertrophy and then failure. $\mathrm{PAH}$ is a clinical term to describe a very rare idiopathic disease (prevalence 1-2 per 1,000,000 individuals) with poor prognosis (survival of less than 3 years from diagnosis in the absence of treatment). The first symptoms appear when resting mean systolic pulmonary arterial pressure is greater than 20 $\mathrm{mmHg}$. PAH is morphologically and histologically characterized by neomuscularization of small pulmonary arteries with thick intima, hypertrophy of media, adventitial proliferation, and abnormal deposition of extracellular matrix. Progression of vascular remodeling results in narrowing of lumen, increase in pulmonary arterial pressure, and irreversible PAH (Chan \& Loscalzo, 2008). Apart from this idiopathic form, pulmonary hypertension can be caused by 
hemolytic anemia, HIV infection, or genetic mutations in BMPR2 gene. A prolonged stay in high altitude may also, due to chronic hypoxia, induce pulmonary hypertension in predisposed persons. In 1980s and 1990s, prolonged use of anorectic agents such as benfluorex, dexfenfluramine and fenfluramine, now withdrawn from market, increased risk of developing pulmonary hypertension by a factor of 23 (Weir, et al., 2008). Very recently, an increase in pulmonary arterial hypertension and of valvular heart disease has been observed in patients with Parkinson's disease treated with ergot derivatives, used for their agonist properties on dopaminergic receptors, pergolide or cabergoline, which are also agonists of 5$\mathrm{HT}_{2 \mathrm{~B}}$ receptors, but not with lisuride or terguride, which are not (Jahnichen, et al., 2005).

Numerous arguments support current interest for serotonin in experimental and human PAH. Experimental data have identified determinant action of serotonin in pathophysiology of PAH. Serotonin has vasoconstrictive and mitotic actions on vascular smooth muscle cells. Expression of SERT and serotonin 5- $\mathrm{HT}_{1 \mathrm{~B}}, 2 \mathrm{~A}, 2 \mathrm{~B}$ and 7 receptors is detected in endothelial and smooth muscle cells of pulmonary arteries. Analysis of mitotic response of smooth muscle cells isolated from normal pulmonary arteries or from patients with PAH confirms marked increased mitotic activity of serotonin on PAH smooth muscle cells.

Genetically, long allelic variant of SERT promoter is associated with an increase in smooth muscle proliferation; homozygous form of this variant was proposed to be associated with idiopathic PAH in patients, but a broader study of SERT polymorphisms did not confirm this association (Machado, et al., 2006). In rats, chronic hypoxia and serotonin cause extensive vascular remodeling. Similarly, overexpression of SERT gene in mice caused spontaneous development of PAH in the absence of hypoxia and exaggeration of pulmonary hypertension after hypoxic stimulus. Conversely, vessel remodeling and hypoxic pulmonary hypertension are reduced in mutant mice for 5- $\mathrm{HT}_{1 \mathrm{~B}}$ receptor or for SERT (Chan \& Loscalzo, 2008). Therefore, serotonin-signaling pathway modulates pulmonary vascular smooth muscle function, both in normal conditions and at disease stage, and is likely to contribute to PAH progression. However, exact mechanism remains to be specified. SSRIs, which transiently increase serotonin levels by inhibiting serotonin uptake, have no effect on hypoxic PAH development. On the contrary, an association between late maternal use of SSRI and persistent neonatal pulmonary hypertension was observed (Chambers, et al., 2006). Therefore, it is currently unclear whether serotonin itself or combination of its primary effectors leads to PAH development.

High plasma serotonin concentrations are found in patients with PAH. A positive correlation between these concentrations and right ventricular pressure was observed in more than $80 \%$ of patients with PAH (Hervé, et al., 1995). Drugs that can cause pulmonary hypertension, such as aminorex, pergolide, fenfluramine, and dexfenfluramine (or at least their active metabolites) are potentially capable of releasing serotonin, although they are 5$\mathrm{HT}_{2}$ receptor agonists and more precisely at 5- $\mathrm{HT}_{2 \mathrm{~B}}$ subtype. Stimulation of serotonin release could contribute to increased serotonin plasma concentrations and to activation of serotonergic receptors. Chronic exposure to hypoxia (simulating high altitude) leads to overexpression of 5- $\mathrm{HT}_{2 \mathrm{~B}}$ (and 5- $\mathrm{HT}_{1 \mathrm{~B}}$ ) receptors. Pulmonary hypertension is associated with a substantial increase in 5- $\mathrm{HT}_{2 \mathrm{~B}}$ (and $5-\mathrm{HT}_{1 \mathrm{~B}}$ ) receptor expression in pulmonary arteries of rodents and humans (Dumitrascu, et al., 2011; Launay, et al., 2002). Hypoxia-induced PAH in mice is significantly potentiated by administration of therapeutic doses of dexfenfluramine. On the contrary, occurrence of hypoxia-induced PAH in mice is completely prevented in the presence of a selective antagonist of 5- $\mathrm{HT}_{2 \mathrm{~B}}$ receptors, RS-127445. Similarly, Htr $2 \mathrm{~b}^{-/-}$mice do not develop PAH following chronic exposure to hypoxia and administration of dexfenfluramine (Launay, et al., 2002). Experiments using pulmonary vascular smooth muscle cells have shown that activation of $5-\mathrm{HT}_{2 \mathrm{~B}}$ receptors can also initiate cell cycle progression and mitogenesis. By analyzing $5-\mathrm{HT}_{2 \mathrm{~B}}$-receptor gene in patients who developed 
PAH after taking fenfluramine, a heterozygous mutation was found. This mutated receptor exhibits greater cellular proliferation efficacy in particular in response to nordexfenfluramine (the active metabolite of dexfenfluramine) and serotonin due to exclusive coupling to Ga13 protein (Deraet, et al., 2005). Recently, adults accustomed to high altitude exercise were treated with a 5- $\mathrm{HT}_{2 \mathrm{~B}}$-receptor antagonist compound developed by Epix, PRX08066. These healthy individuals exhibited a reduction in pulmonary systolic pressure during exercise in hypoxia with no effect on systemic pressure. A Phase II clinical trial investigating effects of this compound in hypertension secondary to chronic obstructive pulmonary disease (COPD) was published in August 2007. Over 58 patients treated with $400 \mathrm{mg}$ of PRX08066, 44\% showed a small reduction of pulmonary systolic pressure, PRX-08066 having no effect on systemic blood pressure (Rhodes, et al., 2009). Using monocrotaline-induced pulmonary hypertension model, recent studies confirmed that other 5- $\mathrm{HT}_{2 \mathrm{~B}}$ receptor antagonists (terguride, PRX-08066, or C-122) significantly reduced pulmonary pressure, arterial wall thickening and lumen occlusion but maintained cardiac function (Dumitrascu, et al., 2011; Porvasnik, et al., 2010; Zopf, et al., 2011).

Serotonin may also influence other regulatory pathways involved in the progression of $\mathrm{PAH}$; in particular, serotonin can inhibit BMP signaling pathway by modulation of downstream Smad proteins. Interaction with this signaling pathway is strongly suspected since chronic administration of serotonin increases pulmonary blood pressure and vascular remodeling in heterozygous mice for $B m p r 2$ gene, $B m p r 2^{+/-}$, and potentiates effects of hypoxia. Perturbation of these signaling pathways may be an important co-factor with hypoxia in pathogenesis of PAH (Long, et al., 2006). Both BMPR2 mutation and agonists to $5-\mathrm{HT}_{2 \mathrm{~B}}$ receptors have been shown to cause activation of SRC tyrosine kinase; conversely, antagonists to $5-\mathrm{HT}_{2 \mathrm{~B}}$ receptors inhibit SRC trafficking and downstream function. In Bmpr2R899X knock-in mice, which spontaneously develop pulmonary hypertension, the 5$\mathrm{HT}_{2 \mathrm{~B}}$ receptor antagonist, SB204741, blocked SRC activation caused by Bmpr2R899X mutation. SB204741 prevented development of pulmonary hypertension, reduced recruitment of inflammatory cells to lungs, reduced muscularization of blood vessels, reduced SRC phosphorylation and downstream activity in Bmpr $2 R 899 \mathrm{X}$ mice. Heritable pulmonary hypertension results from increased SRC activation, cellular contraction, and vascular resistance, but antagonism of 5- $\mathrm{HT}_{2 \mathrm{~B}}$ receptors prevents SRC phosphorylation, downstream activity, and pulmonary hypertension in Bmpr $2 R 899 X$ mice (West, et al., 2016).

Using bone-marrow transplantation, restricted expression of 5- $\mathrm{HT}_{2 \mathrm{~B}}$ receptors to bonemarrow cells was shown necessary and sufficient for hypoxia- or monocrotaline-induced pulmonary hypertension to develop, validating an action of serotonin at hematopoietic stem cell differentiation (Launay, et al., 2012). Interestingly, Bmpr2R899X bone-marrow cells were also shown to cause spontaneous pulmonary hypertension with remodeling and inflammation when transplanted into control mice, while control bone-marrow cells had a protective effect against disease development, when transplanted into Bmpr2R899X mutant mice. Donor bone marrow derived cells were found in lungs of recipient mice. Functional and molecular analysis identified mutant bone-marrow cells dysfunction suggestive of a pulmonary hypertension phenotype soon after transplantation and long before development of lung pathology. Bone-marrow cells play thus a key role in genetic pulmonary hypertension pathogenesis given that transplanted Bmpr2R899X bone-marrow cells were able to drive lung phenotype (Yan, et al., 2016).

Together, these findings reveal the role of serotonin in PAH development and shift the contribution of serotonin to PAH to an extrapulmonary, hematopoietic event. 


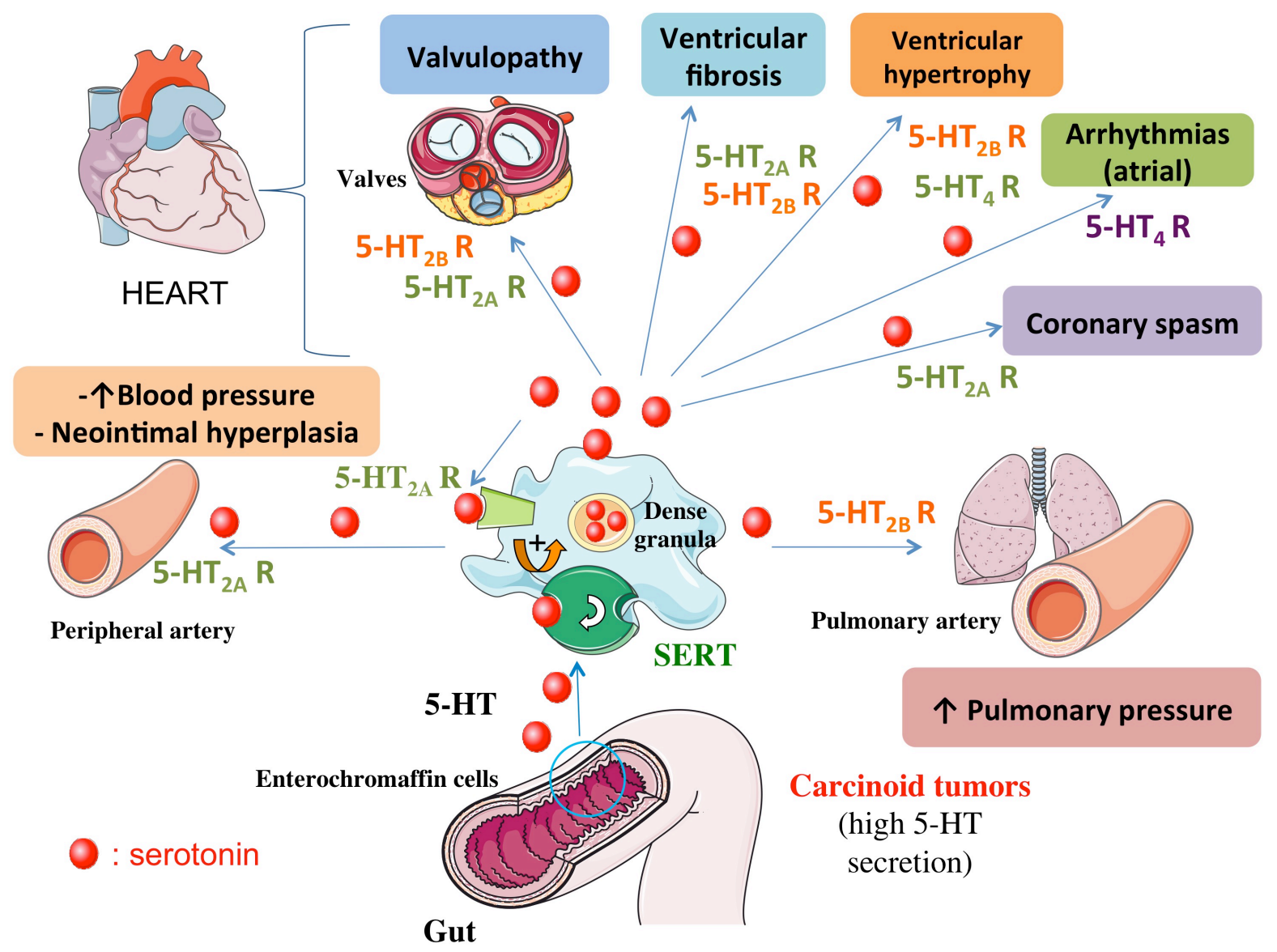

Figure . Cardiovascular pathologies associated to 5-hydroxytryptamine (5-HT; serotonin) and serotonergic receptors $(\mathrm{R})$. 
Table . Distribution and functions of 5-hydroxytryptamine receptors in the cardiovascular system.

Receptors (5-HT) Distribution Physiological functions

$\begin{array}{lll}\text { 5-HT1B } & \text { Smooth muscle cells (arteries and veins) } & \text { Vasoconstriction } \\ & \text { Endothelial cells (small vessels) } & \text { Vasodilatation } \\ \text { 5-HT2A } & \text { Poronary arteries } & \text { Vasoconstriction } \\ & \text { Smooth muscle cells (arteries and veins) } & \text { Vasoconstriction } \\ & \text { Coronary arteries } & \text { Vasoconstriction } \\ \text { 5-HT2B } & \text { Endothelial cells (arteries) } & \text { Vasodilatation } \\ & \text { Cardiomyocytes/ fibroblasts } & \text { Cardiac embryogenesis } \\ \text { 5-HT4 } & \text { Cardiac atria and ventricle } & \text { Positive inotropic } \\ & & \text { Lusitropic effects } \\ & & \text { S-HT7 }\end{array}$

(Monassier, et al., 2010). 5-HT: 5-hydroxytryptamine (serotonin). 


\section{References}

Alexander, S. P. H., Benson, H. E., Faccenda, E., Pawson, A. J., Sharman, J. L., Spedding, M., Peters, J. A., Harmar, A. J., \& Collaborators, C. (2013). The concise guide to pharmacology 2013/14: G protein-coupled receptors. Br J Pharmacol, 170, 1459-1581.

Amireault, P., \& Dube, F. (2005). Intracellular cAMP and calcium signaling by serotonin in mouse cumulus-oocyte complexes. Mol Pharmacol, 68, 1678-1687.

Antonini, A., \& Poewe, W. (2007). Fibrotic heart-valve reactions to dopamine-agonist treatment in Parkinson's disease. Lancet Neurol, 6, 826-829.

Arinami, T., Ohtsuki, T., Yamakawa-Kobayashi, K., Amemiya, H., Fujiwara, H., Kawata, K., Ishiguro, H., \& Hamaguchi, H. (1999). A synergistic effect of serotonin transporter gene polymorphism and smoking in association with CHD. Thromb Haemost, 81, 853856.

Ayme-Dietrich, E., Lawson, R., Côté, F., de Tapia, C., Da Silva, S., Ebel, C., Hechler, B., Gachet, C., Guyonnet, J., Rouillard, H., Stoltz, J., Quentin, E., Banas, S., Daubeuf, F., Frossard, N., Gasser, B., Mazzucotelli, J., Hermine, O., Maroteaux, L., \& Monassier, L. (2017). Serotonergic 5-HT2B receptors in mitral valvulopathy: bone marrow mobilization of endothelial progenitors. Br J Pharmacol, 174, 4123-4141.

Ayme-Dietrich, E., Lawson, R., Gasser, B., Dallemand, R., Bischoff, N., \& Monassier, L. (2012). Mitral bioprosthesis hypertrophic scaring and native aortic valve fibrosis during benfluorex therapy. Fundam Clin Pharmacol, 26, 215-218.

Ayme-Dietrich, E., Marzak, H., Lawson, R., Mokni, W., Wendling, O., Combe, R., Becker, J., El Fertak, L., Champy, M., Matz, R. L., Andriantsitohaina, R., Doly, S., Boutourlinsky, K., Maroteaux, L., \& Monassier, L. (2015). Contribution of serotonin to cardiac remodeling associated with hypertensive diastolic ventricular dysfunction in rats. J Hypertens, 33, 2310-2321.

Bach, T., Syversveen, T., Kvingedal, A. M., Krobert, K. A., Brattelid, T., Kaumann, A. J., \& Levy, F. O. (2001). 5-HT4(a) and 5-HT4(b) receptors have nearly identical pharmacology and are both expressed in human atrium and ventricle. Naunyn-Schmied Arch Pharmacol, 363, 146-160.

Bai, C.-F., Liu, J.-C., Zhao, R., Cao, W., Liu, S.-B., Zhang, X.-N., Guo, H.-J., Yang, Q., Yi, D.-H., \& Zhao, M.-G. (2010). Role of 5-HT2B receptor in cardiomyocyte apoptosis of norepinephrine-induced cardiomyopathy model in rats. Clin Exp Pharmacol Physiol, 37, e145-e151.

Banes, A. K., Loberg, R. D., Brosius, F. C., 3rd, \& Watts, S. W. (2001). Inability of serotonin to activate the c-Jun $\mathrm{N}$-terminal kinase and p38 kinase pathways in rat aortic vascular smooth muscle cells. BMC Pharmacol, 1,8 .

Birkeland, J. A. K., Sjaastad, I., Brattelid, T., Qvigstad, E., Moberg, E. R., Krobert, K. A., Bjørnerheim, R., Skomedal, T., Sejersted, O. M., Osnes, J.-B., \& Levy, F. O. (2007). Effects of treatment with a 5-HT4 receptor antagonist in heart failure. Br J Pharmacol, 150, 143-152.

Blasco-Fontecilla, H., Baca-Garcia, E., \& de Leon, J. (2010). Do atypical antipsychotic drugs reduce the risk of ischemic heart disease and mortality? Possible role of 5-HT2A receptor blockade. Schizophr Res, 119, 160-163.

Brattelid, T., Qvigstad, E., Birkeland, J. A., Swift, F., Bekkevold, S. V., Krobert, K. A., Sejersted, O. M., Skomedal, T., Osnes, J. B., Levy, F. O., \& Sjaastad, I. (2007). Serotonin responsiveness through 5-HT2A and 5-HT4 receptors is differentially regulated in hypertrophic and failing rat cardiac ventricle. J Mol Cell Cardiol, 43, 767779 . 
Brattelid, T., Qvigstad, E., Lynham, J. A., Molenaar, P., Aass, H., Geiran, O., Skomedal, T., Osnes, J. B., Levy, F. O., \& Kaumann, A. J. (2004). Functional serotonin 5-HT4 receptors in porcine and human ventricular myocardium with increased 5-HT4 mRNA in heart failure. Naunyn-Schmied Arch Pharmacol, 370, 157-166.

Brattelid, T., Qvigstad, E., Moltzau, L. R., Bekkevold, S. V. S., Sandnes, D. L., Birkeland, J. A. K., Skomedal, T., Osnes, J.-B., Sjaastad, I., \& Levy, F. O. (2012). The cardiac ventricular 5-HT4 receptor is functional in late foetal development and is reactivated in heart failure. PloS one, 7, e45489.

Buzzi, M. G., Carter, W. B., Shimizu, T., Heath, H. d., \& Moskowitz, M. A. (1991). Dihydroergotamine and sumatriptan attenuate levels of CGRP in plasma in rat superior sagittal sinus during electrical stimulation of the trigeminal ganglion. Neuropharmacology, 30, 1193-1200.

Castanheira, J., Valente-Dos-Santos, J., Costa, D., Martinho, D., Fernandes, J., Duarte, J., Sousa, N., Vaz, V., Rama, L., Figueiredo, A., \& Coelho-E-Silva, M. (2017). Cardiac remodeling indicators in adolescent athletes. Revista da Associacao Medica Brasileira (1992), 63, 427-434.

Castro, L., Mialet-Perez, J., Guillemeau, A., Stillitano, F., Zolk, O., Eschenhagen, T., Lezoualc'h, F., Bochet, P., \& Fischmeister, R. (2005). Differential functional effects of two 5-HT4 receptor isoforms in adult cardiomyocytes. J Mol Cell Cardiol, 39, 335-344.

Chambers, C. D., Hernandez-Diaz, S., Van Marter, L. J., Werler, M. M., Louik, C., Jones, K. L., \& Mitchell, A. A. (2006). Selective serotonin-reuptake inhibitors and risk of persistent pulmonary hypertension of the newborn. $N$ Engl J Med, 354, 579-587.

Chan, S. Y., \& Loscalzo, J. (2008). Pathogenic mechanisms of pulmonary arterial hypertension. J Mol Cell Cardiol, 44, 14-30.

Chandra, M., Gupta, V., Johri, A. K., Misra, R., Kumar, A., Gujrati, V., \& Shanker, K. (1994). Serotonergic mechanisms in heart failure. Indian Heart J, 46, 153-156.

Chang Chien, C.-C., Hsin, L.-W., \& Su, M.-J. (2015). Activation of serotonin 5-HT 7 receptor induces coronary flow increase in isolated rat heart. Eur J Pharmacol, 748, 68-75.

Chen, Y. X., Wang, W. D., Song, X. J., Gu, Y. Q., Tian, H. Y., Hu, H. J., Zhao, J. C., Li, X. Q., \& Liu, C. W. (2015). Prospective randomized study of Sarpogrelate versus Clopidogrel-based dual antiplatelet therapies in patients undergoing femoropopliteal arterial endovascular interventions: preliminary results. Chin Med J (Engl), 128, 15631566.

Choi, D.-S., Ward, S., Messaddeq, N., Launay, J.-M., \& Maroteaux, L. (1997). 5-HT2B receptor-mediated serotonin morphogenetic functions in mouse cranial neural crest and myocardiac cells. Development, 124, 1745-1755.

Connolly, H. M., Crary, J. L., McGoon, M. D., Hensrud, D. D., Edwards, B. S., Edwards, W. D., \& Schaff, H. V. (1997). Valvular heart disease associated with fenfluraminephentermine. N Engl J Med, 337, 581-588.

Corominas, R., Sobrido, M. J., Ribasés, M., Cuenca-León, E., Blanco-Arias, P., Narberhaus, B., Roig, M., Leira, R., López-González, J., Macaya, A., \& Cormand, B. (2010). Association study of the serotoninergic system in migraine in the Spanish population. Am J Med Genet B, 153B, 177-184.

Cote, F., Fligny, C., Bayard, E., Launay, J. M., Gershon, M. D., Mallet, J., \& Vodjdani, G. (2007). Maternal serotonin is crucial for murine embryonic development. Proc Natl Acad Sci U S A, 104, 329-334.

Coto, E., Reguero, J. R., Alvarez, V., Morales, B., Batalla, A., Gonzalez, P., Martin, M., Garcia-Castro, M., Iglesias-Cubero, G., \& Cortina, A. (2003). 5-Hydroxytryptamine 5HT2A receptor and 5-hydroxytryptamine transporter polymorphisms in acute myocardial infarction. Clin Sci (Lond), 104, 241-245. 
Deraet, M., Manivet, P., Janoshazi, A., Callebert, J., Guenther, S., Drouet, L., Launay, J. M., \& Maroteaux, L. (2005). The natural mutation encoding a C terminus-truncated 5Hydroxytryptamine2B receptor is a gain of proliferative functions. Mol Pharmacol, 67, 983-991.

Doggrell, S. A. (2004). Sarpogrelate: cardiovascular and renal clinical potential. Expert Opin Investig Drugs, 13, 865-874.

Droogmans, S., Cosyns, B., D'Haenen, H., Creeten, E., Weytjens, C., Franken, P. R., Scott, B., Schoors, D., Kemdem, A., Close, L., Vandenbossche, J. L., Bechet, S., \& Van Camp, G. (2007a). Possible association between 3,4-methylenedioxymethamphetamine abuse and valvular heart disease. Am J Cardiol, 100, 1442-1445.

Droogmans, S., Franken, P. R., Garbar, C., Weytjens, C., Cosyns, B., Lahoutte, T., Caveliers, V., Pipeleers-Marichal, M., Bossuyt, A., Schoors, D., \& Van Camp, G. (2007b). In vivo model of drug-induced valvular heart disease in rats: pergolide-induced valvular heart disease demonstrated with echocardiography and correlation with pathology. Eur Heart $J, 28,2156-2162$.

Dumitrascu, R., Kulcke, C., Königshoff, M., Kouri, F., Yang, X., Morrell, N., Ghofrani, H. A., Weissmann, N., Reiter, R., Seeger, W., Grimminger, F., Eickelberg, O., Schermuly, R. T., \& Pullamsetti, S. S. (2011). Terguride ameliorates monocrotaline-induced pulmonary hypertension in rats. Eur Respir J, 37, 1104-1118.

Elangbam, C. S. (2010). Drug-induced valvulopathy: an update. Toxicol Pathol, 38, 837-848.

Elangbam, C. S., Job, L. E., Zadrozny, L. M., Barton, J. C., Yoon, L. W., Gates, L. D., \& Slocum, N. (2008). 5-hydroxytryptamine (5-HT)-induced valvulopathy: compositional valvular alterations are associated with 5-HT2B receptor and 5-HT transporter transcript changes in Sprague-Dawley rats. Exp Toxicol Pathol, 60, 253-262.

Elangbam, C. S., Lightfoot, R. M., Yoon, L. W., Creech, D. R., Geske, R. S., Crumbley, C. W., Gates, L. D., \& Wall, H. G. (2005). 5-Hydroxytryptamine (5-HT) receptors in the heart valves of cynomolgus monkeys and Sprague-Dawley rats. J Histochem Cytochem, 53, 671-677.

Ferrans, V. J., \& Roberts, W. C. (1976). The carcinoid endocardial plaque; an ultrastructural study. Hum Pathol, 7, 387-409.

Ferrari, M. D. (1998). Migraine. Lancet, 351, 1043-1051.

Fitzgerald, L. W., Burn, T. C., Brown, B. S., Patterson, J. P., Corjay, M. H., Valentine, P. A., Sun, J.-H., Link, J. R., Abbaszade, I., Hollis, J. M., Largent, B. L., Hartig, P. R., Hollis, G. F., Meunier, P. C., Robichaud, A. J., \& Robertson, D. W. (2000). Possible role of valvular serotonin 5-HT2B receptors in the cardiopathy associated with fenfluramine. Mol Pharmacol, 57, 75-81.

Fox, D. J., \& Khattar, R. S. (2004). Carcinoid heart disease: presentation, diagnosis, and management. Heart, 90, 1224-1228.

Fox, S. H. (2014). Pimavanserin as treatment for Parkinson's disease psychosis. Lancet, 383, 494-496.

Fujita, M., Minamino, T., Sanada, S., Asanuma, H., Hirata, A., Ogita, H., Okada, K., Tsukamoto, O., Takashima, S., Tomoike, H., Node, K., Hori, M., \& Kitakaze, M. (2004). Selective blockade of serotonin 5-HT2A receptor increases coronary blood flow via augmented cardiac nitric oxide release through 5-HT1B receptor in hypoperfused canine hearts. J Mol Cell Cardiol, 37, 1219-1223.

Fumeron, F., Betoulle, D., Nicaud, V., Evans, A., Kee, F., Ruidavets, J. B., Arveiler, D., Luc, G., \& Cambien, F. (2002). Serotonin transporter gene polymorphism and myocardial infarction: Etude Cas-Temoins de l'Infarctus du Myocarde (ECTIM). Circulation, 105, 2943-2945. 
Gaddum, J. H., \& Picarelli, Z. P. (1957). Two kinds of tryptamine receptors. Br J Pharmacol, 12, 323-328.

Garcia-Pedraza, J. A., Garcia, M., Martin, M. L., San Roman, L., \& Moran, A. (2014). The role of endothelium-derived hyperpolarizing factor and cyclooxygenase pathways in the inhibitory serotonergic response to the pressor effect elicited by sympathetic stimulation in chronic sarpogrelate treated rats. Eur J Pharmacol, 731, 80-87.

Gelernter, J., Cubells, J. F., Kidd, J. R., Pakstis, A. J., \& Kidd, K. K. (1999). Population studies of polymorphisms of the serotonin transporter protein gene. Am J Med Genet, 88, 61-66.

Goadsby, P. J., Lipton, R. B., \& Ferrari, M. D. (2002). Migraine-current understanding and treatment. $N$ Engl J Med, 346, 257-270.

Goichot, B., Grunenberger, F., Trinh, A., Mazzucotelli, J. P., Weber, J. C., Vinzio, S., \& Schlienger, J. L. (2005). [Carcinoid heart disease: an underestimated complication of endocrine digestive tumors]. Gastroenterol Clin Biol, 29, 997-1000.

Gustafsson, B. I., Tommeras, K., Nordrum, I., Loennechen, J. P., Brunsvik, A., Solligard, E., Fossmark, R., Bakke, I., Syversen, U., \& Waldum, H. (2005). Long-term serotonin administration induces heart valve disease in rats. Circulation, 111, 1517-1522.

Hanna, G. L., Himle, J. A., Curtis, G. C., Koram, D. Q., Veenstra-VanderWeele, J., Leventhal, B. L., \& Cook, E. H., Jr. (1998). Serotonin transporter and seasonal variation in blood serotonin in families with obsessive-compulsive disorder. Neuropsychopharmacology, 18, 102-111.

Hart, E. A., Meijs, T. A., Meijer, R. C. A., Dreijerink, K. M., Tesselaar, M. E., de Groot, C. A., Valk, G. D., \& Chamuleau, S. A. J. (2017). Carcinoid heart disease: a guide for screening and timing of surgical intervention. Netherlands heart journal : monthly journal of the Netherlands Society of Cardiology and the Netherlands Heart Foundation, 25, 471-478.

Hayashi, T., Sumi, D., Matsui-Hirai, H., Fukatsu, A., Arockia Rani, P. J., Kano, H., Tsunekawa, T., \& Iguchi, A. (2003). Sarpogrelate HCl, a selective 5-HT2A antagonist, retards the progression of atherosclerosis through a novel mechanism. Atherosclerosis, $168,23-31$.

Heils, A., Teufel, A., Petri, S., Stober, G., Riederer, P., Bengel, D., \& Lesch, K. P. (1996). Allelic variation of human serotonin transporter gene expression. J Neurochem, 66, 2621-2624.

Hendrikx, M., Van Dorpe, J., Flameng, W., \& Daenen, W. (1996). Aortic and mitral valve disease induced by ergotamine therapy for migraine: a case report and review of the literature. J Heart Valve Dis, 5, 235-237.

Hergovich, N., Aigner, M., Eichler, H. G., Entlicher, J., Drucker, C., \& Jilma, B. (2000). Paroxetine decreases platelet serotonin storage and platelet function in human beings. Clin Pharmacol Ther, 68, 435-442.

Hervé, P., Launay, J. M., Scrobohaci, M. L., Brenot, F., Simonneau, G., Petitpretz, P., Poubeau, P., Cerrina, J., Duroux, P., \& Drouet, L. (1995). Increased plasma serotonin in primary pulmonary hypertension. Am J Med, 99, 249-254.

Horvath, J., Fross, R. D., Kleiner-Fisman, G., Lerch, R., Stalder, H., Liaudat, S., Raskoff, W. J., Flachsbart, K. D., Rakowski, H., Pache, J. C., Burkhard, P. R., \& Lang, A. E. (2004). Severe multivalvular heart disease: a new complication of the ergot derivative dopamine agonists. Mov Disord, 19, 656-662.

Hoskin, K. L., Kaube, H., \& Goadsby, P. J. (1996). Central activation of the trigeminovascular pathway in the cat is inhibited by dihydroergotamine. A c-Fos and electrophysiological study. Brain, 119, 249-256. 
Hossain, M., Muntasir, H. A., Ishiguro, M., Bhuiyan, M. A., Rashid, M., Sugihara, T., \& Nagatomo, T. (2012). Mechanism of inverse agonist action of sarpogrelate at the constitutively active mutant of human 5-HT2A receptor revealed by molecular modeling. Biol Pharm Bull, 35, 1553-1559.

Iizuka, K., Hamaue, N., Machida, T., Hirafuji, M., \& Tsuji, M. (2009). Beneficial effects of sarpogrelate hydrochloride, a 5-HT2A receptor antagonist, supplemented with pioglitazone on diabetic model mice. Endocr Res, 34, 18-30.

Ishida, T., Kawashima, S., Hirata, K., \& Yokoyama, M. (1998). Nitric oxide is produced via 5-HT1B and 5-HT2B receptor activation in human coronary artery endothelial cells. Kobe J Med Sci, 44, 51-63.

Iwabayashi, M., Taniyama, Y., Sanada, F., Azuma, J., Iekushi, K., Kusunoki, H., Chatterjee, A., Okayama, K., Rakugi, H., \& Morishita, R. (2012). Role of serotonin in angiogenesis: induction of angiogenesis by sarpogrelate via endothelial 5HT1B/Akt/eNOS pathway in diabetic mice. Atherosclerosis, 220, 337-342.

Jaffre, F., Bonnin, P., Callebert, J., Debbabi, H., Setola, V., Doly, S., Monassier, L., Mettauer, B., Blaxall, B. C., Launay, J. M., \& Maroteaux, L. (2009). Serotonin and angiotensin receptors in cardiac fibroblasts coregulate adrenergic-dependent cardiac hypertrophy. Circ Res, 104, 113-123.

Jaffré, F., Callebert, J., Sarre, A., Etienne, N., Nebigil, C. G., Launay, J. M., Maroteaux, L., \& Monassier, L. (2004). Involvement of the serotonin 5-HT2B receptor in cardiac hypertrophy linked to sympathetic stimulation: control of interleukin-6, interleukin-1 beta, and tumor necrosis factor-alpha cytokine production by ventricular fibroblasts. Circulation, 110, 969-974.

Jahnichen, S., Horowski, R., \& Pertz, H. H. (2005). Agonism at 5-HT2B receptors is not a class effect of the ergolines. Eur J Pharmacol, 513, 225-228.

Janeway, T. C., Richadson, H. B., \& Park, E. A. (1918). Experiments on the vasoconstrictor action of blood serum. Arch. Int. Med., 21, 565-603.

Jian, B., Xu, J., Connolly, J., Savani, R. C., Narula, N., Liang, B., \& Levy, R. J. (2002). Serotonin mechanisms in heart valve disease I: serotonin-induced up-regulation of transforming growth factor-betal via G-protein signal transduction in aortic valve interstitial cells. Am J Pathol, 161, 2111-2121.

Johnson, K. W., Nelson, D. L., Dieckman, D. K., Wainscott, D. B., Lucaites, V. L., Audia, J. E., Owton, W. M., \& Phebus, L. A. (2003). Neurogenic dural protein extravasation induced by meta-chlorophenylpiperazine (mCPP) involves nitric oxide and 5-HT2B receptor activation. Cephalalgia, 23, 117-123.

Joynt, K. E., \& O'Connor, C. M. (2005). Lessons from SADHART, ENRICHD, and other trials. Psychosom Med, 67 Suppl 1, S63-66.

Kalkman, H. O. (1994). Is migraine prophylactic activity caused by 5-HT2B or 5-HT2C receptor blockade? Life Sci., 54, 641-644.

Kamel, R., Garcia, S., Lezoualc'h, F., Fischmeister, R., Muller, S., Hoebek, J., \& Eftekhari, P. (2007). Immunomodulation by maternal autoantibodies of the fetal serotoninergic 5HT4 receptor and its consequences in early BALB/c mouse embryonic development. BMC Dev Biol, 7, 34.

Kaumann, A. J., \& Levy, F. O. (2006). Fading of 5-HT4 receptor-mediated inotropic responses to 5-hydroxytryptamine is caused by phosphodiesterase activity in porcine atrium. Br J Pharmacol, 147, 128-130.

Kawamura, M., Ishiguro, M., Nagamine, T., \& Houkin, K. (2013). Sarpogrelate dilates cerebral arteries in the absence of exogenous serotonin. Neurol Med Chir (Tokyo), 53, 291-298. 
Kéreveur, A., Callebert, J., Humbert, M., Hervé, P., Simonneau, G., Launay, J. M., \& Drouet, L. (2000). High plasma serotonin levels in primary pulmonary hypertension : effect of long-term epoprostenol (Prostacyclin) therapy. Arterioscler Thromb Vasc Biol, 20, 2233-2239.

Kjekshus, J. K., Torp-Pedersen, C., Gullestad, L., Kober, L., Edvardsen, T., Olsen, I. C., Sjaastad, I., Qvigstad, E., Skomedal, T., Osnes, J. B., \& Levy, F. O. (2009). Effect of piboserod, a 5-HT4 serotonin receptor antagonist, on left ventricular function in patients with symptomatic heart failure. Eur J Heart Fail, 11, 771-778.

Klein, D., Demory, A., Peyre, F., Kroll, J., Géraud, C., Ohnesorge, N., Schledzewski, K., Arnold, B., \& Goerdt, S. (2009). Wnt2 acts as an angiogenic growth factor for nonsinusoidal endothelial cells and inhibits expression of stanniocalcin-1. Angiogenesis, 12, 251-265.

Kodama, A., Komori, K., Hattori, K., Yamanouchi, D., Kajikuri, J., \& Itoh, T. (2009). Sarpogrelate hydrochloride reduced intimal hyperplasia in experimental rabbit vein graft. J Vasc Surg, 49, 1272-1281.

Kokubu, N., Tsuchihashi, K., Yuda, S., Hase, M., Eguchi, M., Wakabayashi, T., Hashimoto, A., Nakata, T., Miura, T., Ura, N., Nagao, K., Tsuzuki, M., Wakabayashi, C., \& Shimamoto, K. (2006). Persistent insulin-sensitizing effects of sarpogrelate hydrochloride, a serotonin $2 \mathrm{~A}$ receptor antagonist, in patients with peripheral arterial disease. Circ J, 70, 1451-1456.

Kursar, J. D., Nelson, D. L., Wainscott, D., \& Baez, M. (1994). Molecular cloning, functional expression, and mRNA tissue distribution of the human 5-hydroxytryptamine2B receptor. Mol. Pharmacol., 46, 227-234.

Lairez, O., Cognet, T., Schaak, S., Calise, D., Guilbeau-Frugier, C., Parini, A., \& MialetPerez, J. (2013). Role of serotonin 5-HT2A receptors in the development of cardiac hypertrophy in response to aortic constriction in mice. J Neural Transm (Vienna), 120, 927-935.

Lauder, J. M. (1993). Neurotransmitters as growth regulatory signals: role of receptors and second messengers. TINS, 16, 233-240.

Lauder, J. M., Wilkie, M. B., Wu, C., \& Singh, S. (2000). Expression of 5-HT2A, 5-HT2B and 5-HT2C receptors in the mouse embryo. Int J Dev Neurosci, 18, 653-662.

Laugwitz, K.-L., Moretti, A., Lam, J., Gruber, P., Chen, Y., Woodard, S., Lin, L.-Z., Cai, C.L., Lu, M. M., Reth, M., Platoshyn, O., Yuan, J. X.-J., Evans, S., \& Chien, K. R. (2005). Postnatal isl1+ cardioblasts enter fully differentiated cardiomyocyte lineages. Nature, 433, 647-653.

Launay, J.-M., Hervé, P., Callebert, J., Mallat, Z., Collet, C., Doly, S., Belmer, A., Diaz, S. L., Hatia, S., Côté, F., Humbert, M., \& Maroteaux, L. (2012). Serotonin 5-HT2B receptors are required for bone-marrow contribution to pulmonary arterial hypertension. Blood, 119, 1772-1780.

Launay, J. M., Hervé, P., Peoc'h, K., Tournois, C., Callebert, J., Nebigil, C., Etienne, N., Drouet, L., Humbert, M., Simonneau, G., \& Maroteaux, L. (2002). Function of the serotonin 5-hydroxytryptamine 2B receptor in pulmonary hypertension. Nat Med, 8, 1129-1135.

Lenke, R. R., \& Levy, H. R. (1980). Maternal phenylketonuria and hyperphenylalaninemia: an international survey of the outcome of untreated and treated pregnancies. $N$ Eng $J$ Med, 303, 1202-1208.

Lesch, K. P., Bengel, D., Heils, A., Sabol, S. Z., Greenberg, B. D., Petri, S., Benjamin, J., Muller, C. R., Hamer, D. H., \& Murphy, D. L. (1996). Association of anxiety-related traits with a polymorphism in the serotonin transporter gene regulatory region. Science, $274,1527-1531$. 
Levy, F. O., Qvigstad, E., Krobert, K. A., Skomedal, T., \& Osnes, J. B. (2008). Effects of serotonin in failing cardiac ventricle: signalling mechanisms and potential therapeutic implications. Neuropharmacology, 55, 1066-1071.

Liang, Y. J., Lai, L. P., Wang, B. W., Juang, S. J., Chang, C. M., Leu, J. G., \& Shyu, K. G. (2006). Mechanical stress enhances serotonin 2B receptor modulating brain natriuretic peptide through nuclear factor-kappaB in cardiomyocytes. Cardiovasc Res, 72, 303312.

Linder, A. E., Ni, W., Szasz, T., Burnett, R., Diaz, J., Geddes, T. J., Kuhn, D. M., \& Watts, S. W. (2008). A serotonergic system in veins: serotonin transporter-independent uptake. $J$ Pharmacol Exp Ther, 325, 714-722.

Long, L., MacLean, M. R., Jeffery, T. K., Morecroft, I., Yang, X., Rudarakanchana, N., Southwood, M., James, V., Trembath, R. C., \& Morrell, N. W. (2006). Serotonin increases susceptibility to pulmonary hypertension in BMPR2-deficient mice. Circ Res, 98, 818-827.

Louik, C., Lin, A. E., Werler, M. M., Hernandez-Diaz, S., \& Mitchell, A. A. (2007). Firsttrimester use of selective serotonin-reuptake inhibitors and the risk of birth defects. $N$ Engl J Med, 356, 2675-2683.

Machado, R. D., Koehler, R., Glissmeyer, E., Veal, C., Suntharalingam, J., Kim, M., Carlquist, J., Town, M., Elliott, C. G., Hoeper, M., Fijalkowska, A., Kurzyna, M., Thomson, J. R., Gibbs, S. R., Wilkins, M. R., Seeger, W., Morrell, N. W., Gruenig, E., Trembath, R. C., \& Janssen, B. (2006). Genetic association of the serotonin transporter in pulmonary arterial hypertension. Am J Respir Crit Care Med, 173, 793-797.

Machida, T., Ohta, M., Onoguchi, A., Iizuka, K., Sakai, M., Minami, M., \& Hirafuji, M. (2011). 5-Hydroxytryptamine induces cyclooxygenase-2 in rat vascular smooth muscle cells: Mechanisms involving Src, PKC and MAPK activation [corrected]. Eur $J$ Pharmacol, 656, 19-26.

Marzak, H., Ayme-Dietrich, E., Lawson, R., Mokni, W., Combe, R., Becker, J., Fertak, L. E., Champy, M. F., \& Monassier, L. (2014). Old spontaneously hypertensive rats gather together typical features of human chronic left-ventricular dysfunction with preserved ejection fraction. J Hypertens, 32, 1307-1316.

Mialet-Perez, J., D'Angelo, R., Villeneuve, C., Ordener, C., Negre-Salvayre, A., Parini, A., \& Vindis, C. (2012). Serotonin 5-HT2A receptor-mediated hypertrophy is negatively regulated by caveolin-3 in cardiomyoblasts and neonatal cardiomyocytes. $\mathrm{J} \mathrm{Mol} \mathrm{Cell}$ Cardiol, 52, 502-510.

Miyazaki, M., Higashi, Y., Goto, C., Chayama, K., Yoshizumi, M., Sanada, H., Orihashi, K., \& Sueda, T. (2007). Sarpogrelate hydrochloride, a selective 5-HT2A antagonist, improves vascular function in patients with peripheral arterial disease. $J$ Cardiovasc Pharmacol, 49, 221-227.

Monassier, L., Laplante, M. A., Ayadi, T., Doly, S., \& Maroteaux, L. (2010). Contribution of gene-modified mice and rats to our understanding of the cardiovascular pharmacology of serotonin. Pharmacol Ther, 128, 559-567.

Monassier, L., Laplante, M. A., Jaffre, F., Bousquet, P., Maroteaux, L., \& de Champlain, J. (2008). Serotonin 5-HT2B receptor blockade prevents reactive oxygen species-induced cardiac hypertrophy in mice. Hypertension, 52, 301-307.

Muntasir, H. A., Bhuiyan, M. A., Ishiguro, M., Ozaki, M., \& Nagatomo, T. (2006). Inverse agonist activity of sarpogrelate, a selective 5-HT2A-receptor antagonist, at the constitutively active human 5-HT2A receptor. J Pharmacol Sci, 102, 189-195.

Nebigil, C. G., Choi, D.-S., Dierich, A., Hickel, P., Le Meur, M., Messaddeq, N., Launay, J.M., \& Maroteaux, L. (2000a). Serotonin 2B receptor is required for heart development. Proc Natl Acad Sci US A, 97, 9508-9513. 
Nebigil, C. G., Etienne, N., Messaddeq, N., \& Maroteaux, L. (2003). Serotonin is a novel survival factor of cardiomyocytes: mitochondria as a target of 5-HT2B-receptor signaling. FASEB J, 17, 1373-1375.

Nebigil, C. G., Hickel, P., Messaddeq, N., Vonesch, J.-L., Douchet, M.-P., Monassier, L., György, K., Martz, R., Andriantsitohaina, R., Manivet, P., Launay, J.-M., \& Maroteaux, L. (2001). Ablation of serotonin 5-HT2B receptors in mice leads to abnormal cardiac structure and function. Circulation, 103, 2973-2979.

Nebigil, C. G., Launay, J.-M., Hickel, P., Tournois, C., \& Maroteaux, L. (2000b). 5Hydroxytryptamine 2B receptor regulates cell-cycle progression: Cross talk with tyrosine kinase pathways. Proc Natl Acad Sci U S A, 97, 2591-2596.

Ni, W., Lookingland, K., \& Watts, S. W. (2006). Arterial 5-hydroxytryptamine transporter function is impaired in deoxycorticosterone acetate and Nomega-nitro-L-arginine but not spontaneously hypertensive rats. Hypertension, 48, 134-140.

Noskova, T., Pivac, N., Nedic, G., Kazantseva, A., Gaysina, D., Faskhutdinova, G., Gareeva, A., Khalilova, Z., Khusnutdinova, E., Kovacic, D. K., Kovacic, Z., Jokic, M., \& Seler, D. M. (2008). Ethnic differences in the serotonin transporter polymorphism (5HTTLPR) in several European populations. Prog Neuropsychopharm, 32, 1735-1739.

Ohri, S. K., Schofield, J. B., Hodgson, H., Oakley, C. M., \& Keogh, B. E. (1994). Carcinoid heart disease: early failure of an allograft valve replacement. Ann Thorac Surg, 58, 1161-1163.

Orton, E. C., Lacerda, C. M. R., \& MacLea, H. B. (2012). Signaling pathways in mitral valve degeneration. J Vet Cardiol, 14, 7-17.

Pavone, L. M., Spina, A., Lo Muto, R., Santoro, D., Mastellone, V., \& Avallone, L. (2008). Heart valve cardiomyocytes of mouse embryos express the serotonin transporter SERT. Biochem Biophys Res Commun, 377, 419-422.

Pellikka, P. A., Tajik, A. J., Khandheria, B. K., Seward, J. B., Callahan, J. A., Pitot, H. C., \& Kvols, L. K. (1993). Carcinoid heart disease. Clinical and echocardiographic spectrum in 74 patients. Circulation, 87, 1188-1196.

Porvasnik, S. L., Germain, S., Embury, J., Gannon, K. S., Jacques, V., Murray, J., Byrne, B. J., Shacham, S., \& Al-Mousily, F. (2010). PRX-08066, a novel 5-hydroxytryptamine receptor $2 \mathrm{~B}$ antagonist, reduces monocrotaline-induced pulmonary arterial hypertension and right ventricular hypertrophy in rats. J Pharmacol Exp Ther, 334, 364-372.

Prante, C., Milting, H., Kassner, A., Farr, M., Ambrosius, M., Schon, S., Seidler, D. G., Banayosy, A. E., Korfer, R., Kuhn, J., Kleesiek, K., \& Gotting, C. (2007). Transforming growth factor beta1-regulated xylosyltransferase I activity in human cardiac fibroblasts and its impact for myocardial remodeling. J Biol Chem, 282, 26441-26449.

Qvigstad, E., Brattelid, T., Sjaastad, I., Andressen, K. W., Krobert, K. A., Birkeland, J. A., Sejersted, O. M., Kaumann, A. J., Skomedal, T., Osnes, J. B., \& Levy, F. O. (2005). Appearance of a ventricular 5-HT4 receptor-mediated inotropic response to serotonin in heart failure. Cardiovasc Res, 65, 869-878.

Rajamannan, N. M., Caplice, N., Anthikad, F., Sebo, T. J., Orszulak, T. A., Edwards, W. D., Tajik, J., \& Schwartz, R. S. (2001). Cell proliferation in carcinoid valve disease: a mechanism for serotonin effects. J Heart Valve Dis, 10, 827-831.

Rapport, M. M., Green, A. A., \& Page, I. H. (1948a). Crystalline Serotonin. Science, 108, 329-330.

Rapport, M. M., Green, A. A., \& Page, I. H. (1948b). Serum vasoconstrictor, serotonin; isolation and characterization. J Biol Chem, 176, 1243-1251.

Ren, S., Qian, S., Wang, W., Liu, J., \& Liu, P. (2013). Prospective study of sarpogrelate hydrochloride on patients with arteriosclerosis obliterans. Ann Thorac Cardiovasc Surg, 19, 30-34. 
Rhodes, C. J., Davidson, A., Gibbs, J. S., Wharton, J., \& Wilkins, M. R. (2009). Therapeutic targets in pulmonary arterial hypertension. Pharmacol Ther, 121, 69-88.

Ridker, P. M., Chertow, G. M., Karlson, E. W., Neish, A. S., \& Schoen, F. J. (1991). Bioprosthetic tricuspid valve stenosis associated with extensive plaque deposition in carcinoid heart disease. Am Heart J, 121, 1835-1838.

Roberts, W. C. (1997). A unique heart disease associated with a unique cancer: carcinoid heart disease. Am J Cardiol, 80, 251-256.

Robiolio, P. A., Rigolin, V. H., Wilson, J. S., Harrison, J. K., Sanders, L. L., Bashore, T. M., \& Feldman, J. M. (1995). Carcinoid heart disease. Correlation of high serotonin levels with valvular abnormalities detected by cardiac catheterization and echocardiography. Circulation, 92, 790-795.

Roth, B. L. (2007). Drugs and valvular heart disease. N Engl J Med, 356, 6-9.

Rothman, R. B., Baumann, M. H., Savage, J. E., Rauser, L., McBride, A., Hufeisen, S. J., \& Roth, B. L. (2000). Evidence for possible involvement of 5-HT2B receptors in the cardiac valvulopathy associated with fenfluramine and other serotonergic medications. Circulation, 102, 2836-2841.

Roux, C., Madani, M., Launay, J.-M., Rey, F., Citadelle, D., Mulliez, N., \& Kolf, M. (1995). Serotonin deficiency in phenylketonuria embryopathy. Toxicol. in Vitro, 9, 653-662.

Rouzaud-Laborde, C., Delmas, C., Pizzinat, N., Tortosa, F., Garcia, C., Mialet-Perez, J., Payrastre, B., Sié, P., Spreux-Varoquaux, O., Sallerin, B., Carrié, D., Galinier, M., Parini, A., \& Lairez, O. (2015). Platelet activation and arterial peripheral serotonin turnover in cardiac remodeling associated to aortic stenosis. American journal of hematology, 90, 15-19.

Sauer, W. H., Berlin, J. A., \& Kimmel, S. E. (2003). Effect of antidepressants and their relative affinity for the serotonin transporter on the risk of myocardial infarction. Circulation, 108, 32-36.

Saugstad, L. F. (1977). Heterozygote advantage for the phenylketonuria allele. Journal of medical genetics, 14, 20-24.

Schmuck, K., Ullmer, C., Kalkman, H., Probst, A., \& Lübbert, H. (1996). Activation of meningeal 5-HT2B receptors: an early step in the generation of migraine headache? Eur J Neurosci, 8, 959-967.

Setola, V., Hufeisen, S. J., Grande-Allen, K. J., Vesely, I., Glennon, R. A., Blough, B., Rothman, R. B., \& Roth, B. L. (2003). 3,4-Methylenedioxymethamphetamine (MDMA, "Ecstasy") induces fenfluramine-like proliferative actions on human cardiac valvular interstitial cells in vitro. Mol Pharmacol, 63, 1223-1229.

Sharma, S. K., Del Rizzo, D. F., Zahradka, P., Bhangu, S. K., Werner, J. P., Kumamoto, H., Takeda, N., \& Dhalla, N. S. (2001). Sarpogrelate inhibits serotonin-induced proliferation of porcine coronary artery smooth muscle cells: implications for long-term graft patency. Ann Thorac Surg, 71, 1856-1864; discussion 1865.

Shworak, N. W. (2004). Angiogenic modulators in valve development and disease: does valvular disease recapitulate developmental signaling pathways? Curr Opin Cardiol, 19, 140-146.

Simões-Pereira, J., Wang, L. M., Kardos, A., \& Grossman, A. (2017). Carcinoid syndrome and carcinoid heart disease as manifestations of non-metastatic ovarian neuroendocrine tumour. Acta medica portuguesa, 30, 421-425.

Singh, S., Johnson, P. I., Javed, A., Gray, T. S., Lonchyna, V. A., \& Wurster, R. D. (1999). Monoamine- and histamine-synthesizing enzymes and neurotransmitters within neurons of adult human cardiac ganglia. Circulation, 99, 411-419.

Sole, M. J., Shum, A., \& Van Loon, G. R. (1979). Serotonin metabolism in the normal and failing hamster heart. Circ Res, 45, 629-634. 
Somberg, T. C., \& Arora, R. R. (2008). Depression and heart disease: therapeutic implications. Cardiology, 111, 75-81.

Strik, J. J., Honig, A., \& Maes, M. (2001). Depression and myocardial infarction: relationship between heart and mind. Prog Neuropsychopharm, 25, 879-892.

Sun, Y. M., Su, Y., Jin, H. B., Li, J., \& Bi, S. (2011). Sarpogrelate protects against high glucose-induced endothelial dysfunction and oxidative stress. Int J Cardiol, 147, 383387.

Takahara, M., Kaneto, H., Katakami, N., Iida, O., Matsuoka, T. A., \& Shimomura, I. (2014). Effect of sarpogrelate treatment on the prognosis after endovascular therapy for critical limb ischemia. Heart Vessels, 29, 563-567.

Takano, S., Hoshino, Y., Li, L., Matsuoka, I., Ono, T., \& Kimura, J. (2004). Dual roles of 5hydroxytryptamine in ischemia-reperfusion injury in isolated rat hearts. $J$ Cardiovasc Pharmacol Ther, 9, 43-50.

Takishita, E., Takahashi, A., Harada, N., Yamato, M., Yoshizumi, M., \& Nakaya, Y. (2004). Effect of sarpogrelate hydrochloride, a 5-HT2 blocker, on insulin resistance in Otsuka Long-Evans Tokushima fatty rats (OLETF rats), a type 2 diabetic rat model. $J$ Cardiovasc Pharmacol, 43, 266-270.

Tiihonen, J., Lonnqvist, J., Wahlbeck, K., Klaukka, T., Niskanen, L., Tanskanen, A., \& Haukka, J. (2009). 11-year follow-up of mortality in patients with schizophrenia: a population-based cohort study (FIN11 study). Lancet, 374, 620-627.

Ullmer, C., Schmuck, K., Kalkman, H. O., \& Lübbert, H. (1995). Expression of serotonin receptor mRNA in blood vessels. FEBS Lett., 370, 215-221.

Vialli, M., \& Erspamer, V. (1933). Xellule enterochromaffini e cellule basigranulose acidofile nei vertebrati. Z. Zellforsch. Mikrosk. Anat., 19, 743.

Vikenes, K., Farstad, M., \& Nordrehaug, J. E. (1999). Serotonin is associated with coronary artery disease and cardiac events. Circulation, 100, 483-489.

Villalón, C. M., \& Centurión, D. (2007). Cardiovascular responses produced by 5hydroxytriptamine:a pharmacological update on the receptors/mechanisms involved and therapeutic implications. Naunyn-Schmied Arch Pharmacol, 376, 45-63.

Vindis, C., D'Angelo, R., Mucher, E., Negre-Salvayre, A., Parini, A., \& Mialet-Perez, J. (2010). Essential role of TRPC1 channels in cardiomyoblasts hypertrophy mediated by 5-HT2A serotonin receptors. Biochem Biophys Res Commun, 391, 979-983.

Visconti, R. P., Ebihara, Y., LaRue, A. C., Fleming, P. A., McQuinn, T. C., Masuya, M., Minamiguchi, H., Markwald, R. R., Ogawa, M., \& Drake, C. J. (2006). An in vivo analysis of hematopoietic stem cell potential: hematopoietic origin of cardiac valve interstitial cells. Circ Res, 98, 690-696.

Watanabe, T., Pakala, R., Katagiri, T., \& Benedict, C. R. (2001). Serotonin potentiates angiotensin II--induced vascular smooth muscle cell proliferation. Atherosclerosis, 159, 269-279.

Watts, S. W., Baez, M., \& Webb, R. C. (1996). The 5-hydroxytryptamine2B receptor and 5HT receptor signal transduction in mesenteric arteries from deoxycorticosterone acetatesalt hypertensive rats. J Pharmacol Exp Ther, 277, 1103-1113.

Watts, S. W., \& Fink, G. D. (1999). 5-HT2B-receptor antagonist LY-272015 is antihypertensive in DOCA-salt- hypertensive rats. Am J Physiol, 276, H944-952.

Watts, S. W., Gilbert, L., \& Webb, R. C. (1995). 5-Hydroxytryptamine2B receptor mediates contraction in the mesenteric artery of mineralocorticoid hypertensive rats. Hypertension, 26, 1056-1059.

Watts, S. W., Morrison, S. F., Davis, R. P., \& Barman, S. M. (2012). Serotonin and blood pressure regulation. Pharmacol Rev, 64, 359-388. 
Watts, S. W., Darios, E. S., Seitz, B. M., \& Thompson, J. M. (2015). 5-HT is a potent relaxant in rat superior mesenteric veins. Pharmacol Res Perspect, 3, e00103.

Weir, E. K., Obreztchikova, M., \& Hong, Z. (2008). Fenfluramine: riddle or Rosetta stone? Eur Respir J, 31, 232-235.

Weiss, O. (1896). Über die Wirkungen von Blutserum-Injectionen ins Blut. Archiv für die Gesamte Physiologie des Menschen und der Thiere, LXV, 215-230.

West, J. D., Carrier, E. J., Bloodworth, N. C., Schroer, A. K., Chen, P., Ryzhova, L. M., Gladson, S., Shay, S., Hutcheson, J. D., \& Merryman, W. D. (2016). Serotonin 2B Receptor Antagonism Prevents Heritable Pulmonary Arterial Hypertension. PloS one, 11, e0148657.

Whyte, E. M., Pollock, B. G., Wagner, W. R., Mulsant, B. H., Ferrell, R. E., Mazumdar, S., \& Reynolds, C. F., 3rd. (2001). Influence of serotonin-transporter-linked promoter region polymorphism on platelet activation in geriatric depression. Am J Psychiatry, 158, 2074-2076.

Wilkinson, L. O., \& Dourish, C. T. (1991). Serotonin and animal behavior. In S. J. Peroutka (Ed.), Serotonin receptor subtypes: Basic and clinical aspects (Vol. 15, pp. 147-210). New-York: Wiley-Liss.

Xu, J., Jian, B., Chu, R., Lu, Z., Li, Q., Dunlop, J., Rosenzweig-Lipson, S., McGonigle, P., Levy, R. J., \& Liang, B. (2002). Serotonin mechanisms in heart valve disease II: the 5HT2 receptor and its signaling pathway in aortic valve interstitial cells. Am J Pathol, $161,2209-2218$.

Yamada, K., Niki, H., Nagai, H., Nishikawa, M., \& Nakagawa, H. (2012). Serotonin potentiates high-glucose-induced endothelial injury: the role of serotonin and 5-HT2A receptors in promoting thrombosis in diabetes. J Pharmacol Sci, 119, 243-250.

Yan, L., Chen, X., Talati, M., Nunley, B. W., Gladson, S., Blackwell, T., Cogan, J., Austin, E., Wheeler, F., Loyd, J., West, J., \& Hamid, R. (2016). Bone marrow-derived cells contribute to pathogenesis of pulmonary arterial hypertension. Am J Resp Crit Care Med, 193, 898-909.

Yavarone, M. S., Shuey, D. L., Sadler, T. W., \& Lauder, J. M. (1993). Serotonin uptake in the ectoplacental cone and placenta of the mouse. Placenta, 14, 149-161.

Yu, Z., Ohba, M., Nakamura, M., Sasano, T., Ono, M., Sugawara, S., \& Endo, Y. (2009). Dynamics of platelet mobilisation into lungs in response to 5-hydroxytryptamine (serotonin) in mice. Thromb Haemost, 102, 1251-1258.

Zopf, D. A., Neves, L. A. A. d., Nikula, K. J., Huang, J., Senese, P. B., \& Gralinski, M. R. (2011). C-122, a novel antagonist of serotonin receptor 5-HT2B, prevents monocrotaline-induced pulmonary arterial hypertension in rats. Eur J Pharmacol, 670, 195-203.

Zuetenhorst, J. M., Bonfrer, J. M., Korse, C. M., Bakker, R., van Tinteren, H., \& Taal, B. G. (2003). Carcinoid heart disease: the role of urinary 5-hydroxyindoleacetic acid excretion and plasma levels of atrial natriuretic peptide, transforming growth factor-beta and fibroblast growth factor. Cancer, 97, 1609-1615. 